\title{
25. METAMORPHIC ROCKS FROM THE SERPENTINITE SEAMOUNTS IN THE MARIANA AND IZU-OGASAWARA FOREARCS ${ }^{1}$
}

\author{
Hirokazu Maekawa, ${ }^{2.3}$ Masaya Shozui, ${ }^{3}$ Teruaki Ishii, ${ }^{4,5}$ Kristine L. Saboda, ${ }^{6}$ and Yujiro Ogawa ${ }^{7}$
}

\begin{abstract}
During Leg 125, two serpentinite seamounts were drilled in the Mariana and Izu-Ogasawara forearcs. Together with abundant serpentinized peridotites, low-grade metamorphic rocks were recovered from both seamounts. The metamorphic rocks obtained from Hole 778A on Conical Seamount on the Mariana forearc contain common blueschist facies minerals, lawsonite, aragonite, blue amphibole, and sodic pyroxene. Approximate metamorphic conditions of these rocks are $150^{\circ}$ to $250^{\circ} \mathrm{C}$ and 5 to $6 \mathrm{~kb}$. These rocks are considered to have been uplifted by diapirism of serpentinite from a deeper portion within the subduction zone. This discovery presents direct evidence that blueschist facies metamorphism actually takes place within a subduction zone and provides new insight about trench-forearc tectonics.

The diagnostic mineral assemblage of the metamorphic rocks from Holes 783A and 784A on Torishima Forearc Seamount, in the Izu-Ogasawara region, is actinolite + prehnite + epidote, with a subassemblage of chlorite + quartz + albite $+\mathrm{H}_{2} \mathrm{O}$, which is typical of low-pressure type, prehnite-actinolite facies of Liou et al. (1985). This metamorphism may represent ocean-floor metamorphism within trapped oceanic crust or in-situ metamorphism that occurred at depths beneath the island-arc.
\end{abstract}

\section{INTRODUCTION}

A large number of seamounts are exposed to form a narrow zone along the trench axis in the Mariana and Izu-Ogasawara (= Izu-Bonin) forearcs. Recent research based on dredging has revealed that most of these seamounts consist mainly of serpentinized peridotite, with subordinate amounts of gabbro, volcanic rocks of basaltic to dacitic composition, and their metamorphic derivatives (IGCP Working Group, 1977; Honza and Kagami, 1977; Dietrich et al., 1978; Evans and Hawkins, 1979; Hawkins et al., 1979; Bloomer, 1983; Fryer et al., 1985; Ishii, 1985). Studies of dredged samples have focussed on the igneous rocks and indicate that most of these rocks have island-arc affinities, some have intraplate oceanic island affinities, and some are of mid-ocean ridge affinities (e.g., Dietrich et al., 1978; Bloomer, 1983; Bloomer and Hawkins, 1983; Ishii, 1985; Johnson and Fryer, 1990). However, little is known about the types, grades, and genesis of metamorphic rocks, although information about metamorphism is useful for understanding the geology and tectonics of trench-forearc systems.

During Leg 125, two serpentinite seamounts were drilled in the Mariana and Izu-Ogasawara forearcs. Together with abundant serpentinized peridotites, low-grade metamorphic rocks were recovered from both seamounts. This study describes these rocks and discusses briefly their tectonic significance and genesis.

\section{ANALYTICAL METHODS}

Minerals were analyzed with a JEOLJSM-840A scanning electron microscope (SEM) that was equipped with a Kevex energy-dispersive analytical system (EDS) at Kobe University. Accelerating voltage and

'Fryer, P., Pearce, J. A., Stokking, L. B., et al., 1992. Proc. ODP, Sci. Results, 125: College Station, TX (Ocean Drilling Program).

${ }^{2}$ Department of Geology, Western Washington University, Bellingham, WA 98225 , U.S.A.

${ }^{3}$ Department of Earth Sciences, Kobe University, Nada, Kobe 657, Japan.

${ }_{5}^{4}$ NHB-119, Smithsonian Institution, Washington, D.C. 20560, U.S.A.

${ }^{5}$ Ocean Research Institute, University of Tokyo, Nakano, Tokyo 164, Japan.

${ }^{6}$ Hawaii Institute of Geophysics, University of Hawaii at Manoa, Honolulu, HI 96822. U.S.A.

${ }^{7}$ Department of Earth and Planetary Sciences, Kyusyu University, Hakozaki, Fukuoka 812, Japan. beam current were kept at $15.0 \mathrm{kV}$ and $2.0 \mathrm{nA}$, respectively. Corrections were made using the ZAF method. Supplementary microprobe analyses were performed by $\mathrm{T}$. Ishii with an ARL SEMQ microprobe at the Smithsonian Institution, using procedures and standards as described by Jarosewich et al. (1980).

\section{HOLES 778A AND 779A ("CONICAL SEAMOUNT") \\ Petrographical Descriptions}

Three sites were drilled at Conical Seamount in the Mariana forearc about $80 \mathrm{~km}$ west from the trench axis. Two of these (Sites 778 and 779) are on the flanks of the seamount, and one (Site 780) is on its summit. At Site 780, none of the holes contained metamorphic rocks, except for a few highly chloritized rocks. Approximately 60 metamorphosed mafic rocks were recovered from Hole $778 \mathrm{~A}$ and approximately 50 from Hole 779A. Most of the meta-mafic rocks occur as pebble-size clasts of subrounded shape in a serpentinite matrix, but Hole 779A contains a continuous section of metabasalt more than $3 \mathrm{~m}$ long (Sections 125-779A-13R-1 through -13R-3). We carefully selected thirteen specimens from Hole 778A and eight from Hole 779A for this study, which represent the various lithologies present.

Protoliths, identified from their primary textures and mineralogies, are predominantly aphyric to fine-grained basalts and their clastic equivalents, though a late-stage cataclastic deformation and chloritization has commonly obliterated the primary textures and caused difficulty in evaluating the primary origin of these clasts. Variolitic and ophitic to subophitic textures are common. Sample 125-778A-10R-CC (piece 4, $22-24 \mathrm{~cm}$ ) contains megacrysts of plagioclase up to $1 \mathrm{~cm}$ long. Primary clinopyroxene is well-preserved, whereas primary plagioclase and olivine have been completely altered to albite, chlorite or clay minerals. Relict chromian spinel was found in some rocks.

Low-grade metamorphic minerals, such as lawsonite, pumpellyite, and aragonite, occur mainly as vein minerals in the rocks from Hole 778A. Seven specimens characteristically contain lawsonite, pumpellyite, sodic pyroxene, and/or metamorphic aragonite, and one contains blue amphibole (Table 1). The former three are usually present as fillings within cavities and fractures caused by cataclasis. The blue amphibole- and sodic pyroxene-bearing specimen: Sample 125-778A-13R-CC (piece 4, 6-10 cm) contains fragments of clinopyroxenite, serpentinite, and amphibolite in a foliated chlorite and clay matrix. The size of fragments varies from less than $0.2 \mathrm{~mm}$ to 


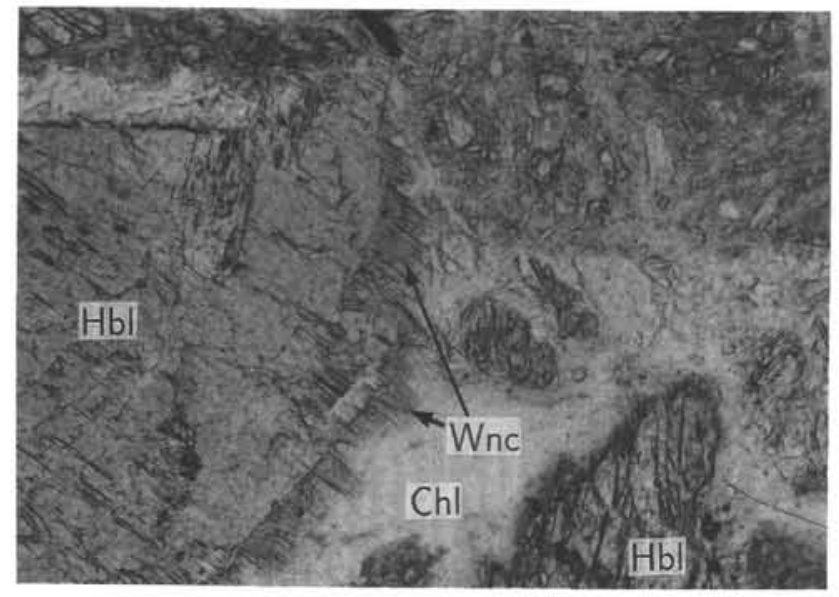

A

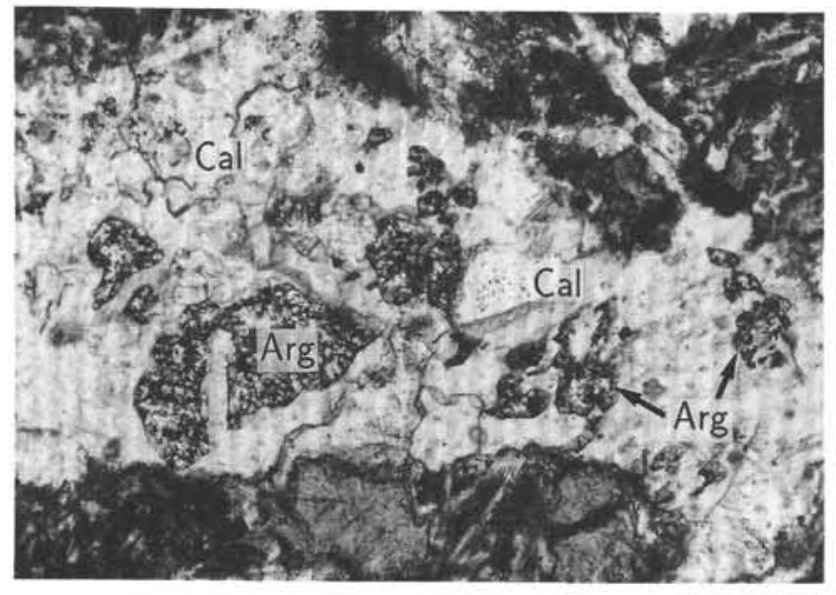

C

$1.75 \mathrm{~cm}$

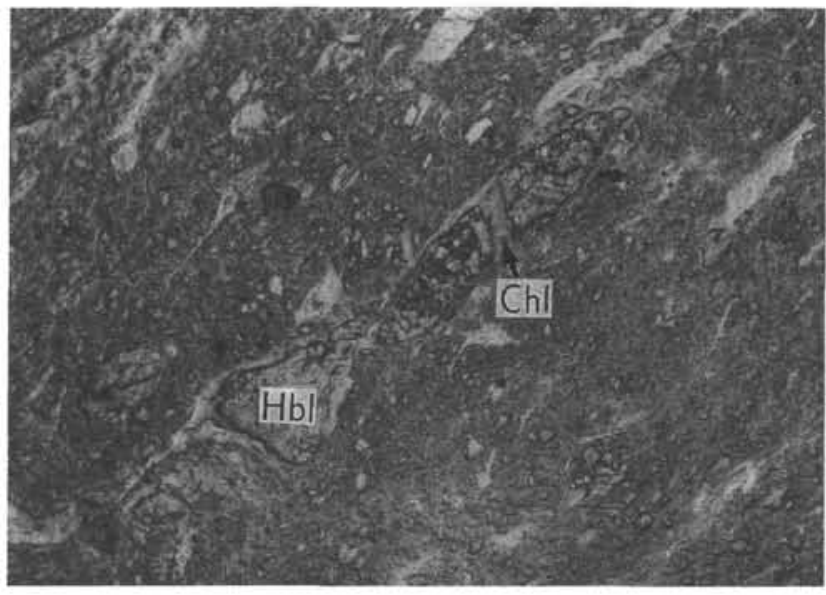

B

$\overline{1.75 \mathrm{~cm}}$

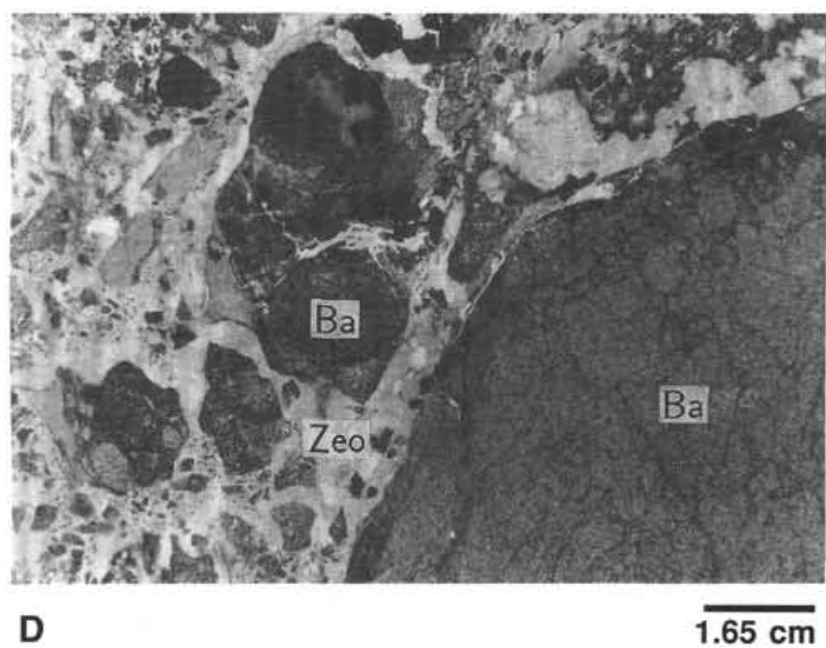

Figure 1. Thin-section photomicrographs (all in plane polarized light) $\mathrm{Hbl}=$ relict hornblende, $\mathrm{Wnc}=$ winchite $, \mathrm{Chl}=\mathrm{chlorite}, \mathrm{Arg}=\mathrm{aragonite}, \mathrm{Cal}=\mathrm{calcite}$, $\mathrm{Ba}=$ basalt fragment, Zeo = zeolite. A. Mode of occurrence of winchite. Sample 125-778A-13R-CC (piece 4, 6-10 cm). B. Pull-apart structure of a hornblende fragment in a dusty matrix. Sample 125-778A-13R-CC (piece 4, 6-10 cm). C. Discrete crystals of aragonite in calcite pool. Aragonite is stained black by Feigl's solution. Discrete crystals bear identical optical orientation, showing simultaneous extinction. Sample 125-778A-7R-1 (2-3 cm). D. Late-stage fracturing of the metabasalt. Sample 125-779A-9R-1 (piece 7B, 93-94 cm). Fractures are filled with zeolite and clay minerals.

more than $8 \mathrm{~mm}$ in a maximum dimension; this clast has a conspicuous foliation, but does not show a lineation. At the surface normal to the foliation, fragments show a boudinage or pull-apart structure (Fig. 1). Because of overprinted deformation, it is uncertain whether the conglomeratic rock is sedimentary or tectonic in origin.

Some examined specimens show evidence for two stages of metamorphism. Sample 125-778A-6R-1 (piece 1, 20-23 cm) is a highly fractured metabasalt composed mainly of actinolitized green hornblende, epidote, albite, and sphene as metamorphic phases, and clinopyroxene as a relict igneous phase (Table 1). Primary ophitic to subophitic textures are well-preserved, but most primary phases have been replaced by metamorphic minerals of greenschist to amphibolite facies. Veins of lawsonite, pumpellyite, and aragonite are low-grade metamorphic products in this sample; the occurrence of these vein minerals suggests that the rock was subsequently metamorphosed under low-grade high $\mathrm{P} / \mathrm{T}$ conditions.

Pumpellyite is common in the recovered samples from Hole 779A, and zeolite and garnet were identified as vein minerals in some rocks. The rocks from Hole 779A lack quartz and albite as a result of intense chloritization, which was probably contemporaneous with serpentinization of the surrounding peridotite. The mineral assemblage pupellyite + garnet + zeolite is significant; as discussed later, the metamorphic conditions of these rocks are considered to differ from those of the Hole 778A rocks.

Although the metamorphic clasts recovered in Leg 125 are thought to have been transported tectonically by serpentinite diapirism, no metasomatic rinds were found at the margins of the examined metamorphic clasts.

\section{Mineralogy}

In the following section, the modes of occurrence and chemistry of the main metamorphic minerals in Holes 778 A and 779A are described. This section also includes descriptions of the relict metamorphic minerals, hornblende, and epidote. The mineral symbols after Kretz (1983) are used where available.

\section{Lawsonite}

Lawsonite was found in the rocks from Hole 778A and confirmed by using X-ray diffraction. It occurs mainly in veins and cavities as an aggregate or radial cluster of fine-grained prismatic or acicular 


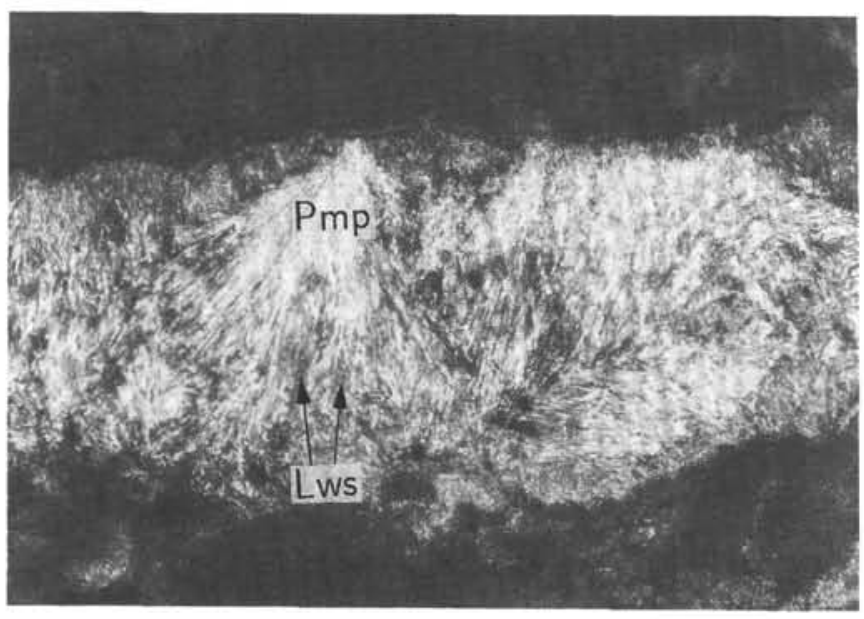

A

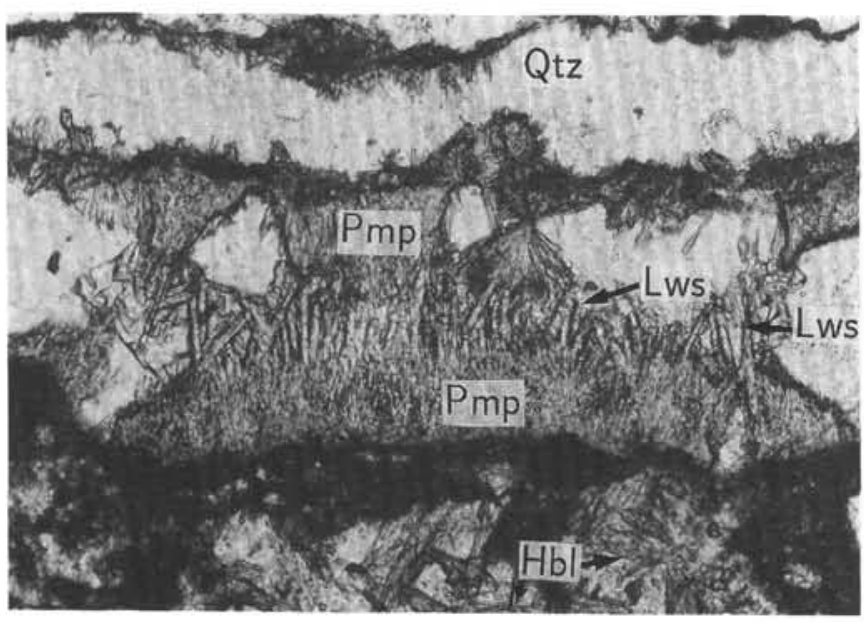

C

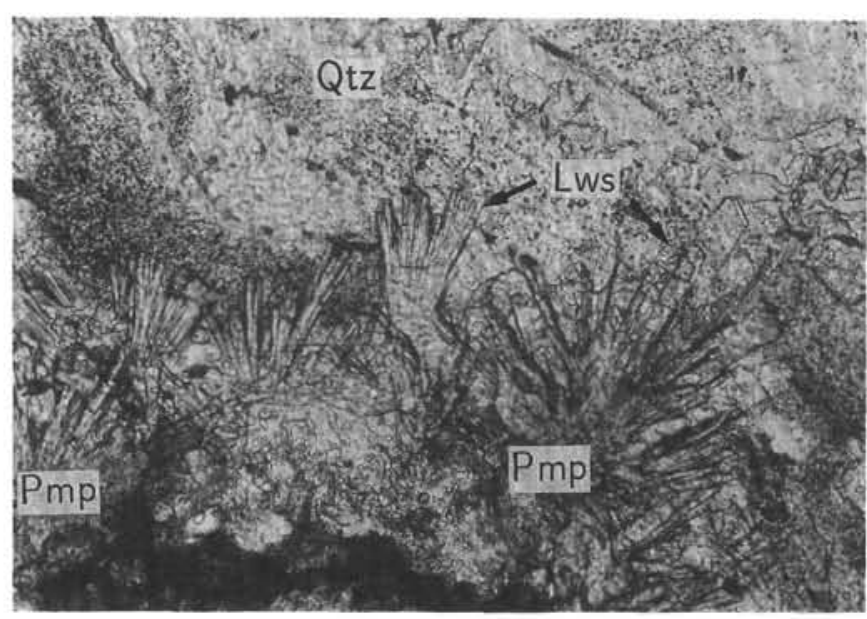

B $\overline{1.75 \mathrm{~cm}}$

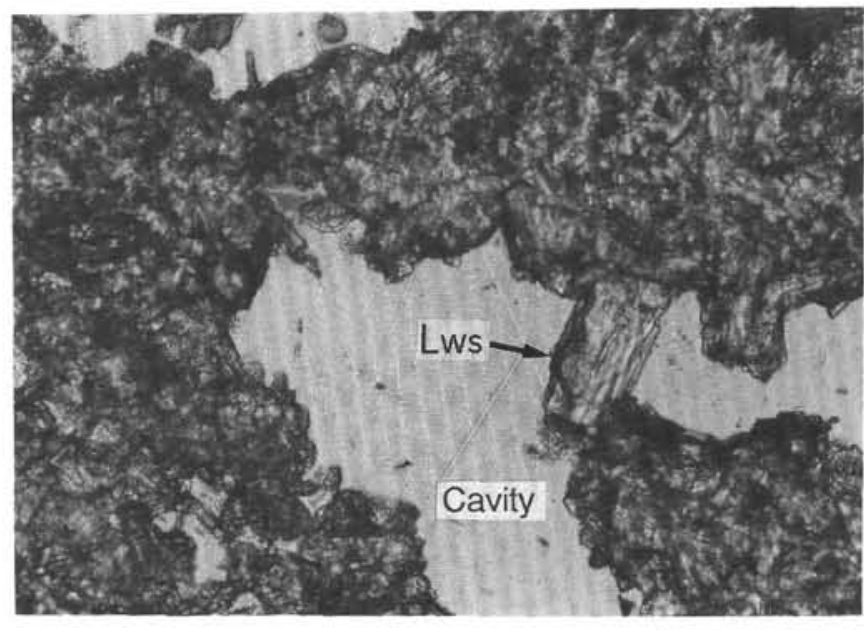

$2.85 \mathrm{~cm}$

Figure 2. Thin-section photomicrographs (all in plane polarized light) showing modes of occurrence of lawsonite and pumpellyite. Pmp = pumpellyite, Lws $=$ lawsonite, Qtz = quartz. Lawsonite is found as overgrowths on pumpellyite (A through $\mathrm{C}$ ) or as an intricate aggregate with pumpellyite (D). The two minerals cannot be distinguished from each other under the microscope, but are easily identified with a back-scattered image of the scanning electron microscope (see Fig. 3). A. Sample 125-778A-11R-1, 5-7 cm. B, C. Sample 125-778A-6R-1 (piece 1, 20-23 cm). D. Sample 125-778A-10R-CC (piece 4, 22-24 cm).

crystals (Fig. 2). In most occurrences, lawsonite is associated intimately with pumpellyite, aragonite, phengite, and quartz. Lawsonite often occurs as overgrowths on pumpellyite and as mixed aggregates with pumpellyite. It is difficult to differentiate lawsonite and pumpellyite because of their small sizes and similar refractive indices. However, they are easily identified with a back scattered image of the SEM (Fig. 3). Microprobe analyses of lawsonite show significant $\mathrm{Fe}^{3+}$ substitution for $\mathrm{Al}$ (Table 2; Fig. 4). Most analyzed lawsonites usually contain 1.5 to $5.0 \mathrm{wt} \% \mathrm{Fe}_{2} \mathrm{O}_{3}$; however, lawsonite in the iron oxidebearing specimen Sample 125-778A-6R-1 (piece 1, 20-23 cm) contains up to $8 \mathrm{wt} \% \mathrm{Fe}_{2} \mathrm{O}_{3}$ and shows a conspicuous zoning from a $\mathrm{Fe}^{3+}$-rich core $(6-8 \mathrm{wt} \%)$ to $\mathrm{Al}$-rich rim $(2-3 \mathrm{wt} \%)$. The $\mathrm{Fe}^{3+} / \mathrm{Al}$ ratios of lawsonite show positive correlation with those of associated pumpellyite, suggesting attainment of equilibrium (Fig. 5). Similar $\mathrm{Fe}^{3+-}$ rich lawsonite with up to $4 \mathrm{wt} \% \mathrm{Fe}_{2} \mathrm{O}_{3}$ has been reported from the Tokoro belt, Japan (aragonite + crossite + aegirine-jadeite grade) (Sakakibara, 1986), and lawsonite with up to $3.2 \mathrm{wt} \% \mathrm{Fe}_{2} \mathrm{O}_{3}$ has been reported from the Franciscan terrane (Maruyama and Liou, 1987). In the latter area, $\mathrm{Fe}_{2} \mathrm{O}_{3}$ in lawsonite tends to decrease with increasing metamorphic grade.

\section{Pumpellyite}

Pumpellyite occurs as small spongy aggregates in both the veins and matrix in rocks from Holes 778 A and 779A. It coexists with lawsonite and aragonite in the rocks from Hole 778A, and with garnet from Hole 779A. Representative analyses of pumpellyite are given in Table 3. $\mathrm{FeO}$ and $\mathrm{Fe}_{2} \mathrm{O}_{3}$ were calculated by assuming the formula $\mathrm{Ca}_{4}$ $\left(\mathrm{Mg}, \mathrm{Fe}^{2+}\right)\left(\mathrm{Al}, \mathrm{Fe}^{3+}\right)_{5} \mathrm{Si}_{6} \mathrm{O}_{21}(\mathrm{OH})_{7}$ (Nakajima et al., 1977). As shown in Figure 6, chemical compositions of pumpellyite from Hole 778 A are apparently affected by the mineral assemblages: pumpellyites in hematite-bearing samples are richer in $\mathrm{Fe}^{3+}$ than those in hematitefree samples (Fig. 6). Pumpellyites from Hole 779A have less $\mathrm{Mg}$ than those from Hole 778A.

\section{Amphiboles}

Ca-amphiboles of the rocks in Hole $778 \mathrm{~A}$ were plotted on a diagram of $\mathrm{Ca}+\mathrm{Na}+\mathrm{K}$ vs. Si (Fig. 7). Representative chemical compositions of Ca-amphiboles are given in Table 4. They are brown to green hornblende and colorless actinolite. The former is a relict 
Table 1. Mineral associations of metamorphosed mafic rocks in Holes 778A and 779A.

\begin{tabular}{|c|c|c|c|c|c|c|c|c|c|c|c|c|c|c|c|c|}
\hline \multirow[b]{2}{*}{$\begin{array}{l}\text { Core, section, } \\
\text { interval }(\mathrm{cm})\end{array}$} & \multirow[b]{2}{*}{$\begin{array}{l}\text { Depth } \\
\text { (mbsf) }\end{array}$} & \multicolumn{15}{|c|}{ Low-grade metamorphic minerals } \\
\hline & & Lws & Pmp & Act & Wnc & $\mathrm{Npx}$ & Chl & Phe & Qtz & $\mathrm{Ab}$ & Cal & Arg & Zeo & Grt & Spn & Opq \\
\hline \multicolumn{17}{|l|}{$125-778 \mathrm{~A}-$} \\
\hline $4 \mathrm{R}-1$ (piece $3,16-19$ ) & 20.4 & & & & & & $\mathrm{x}$ & & & & & & & & $\mathrm{x}$ & \\
\hline $5 \mathrm{R}-1$ (piece $2,7-10$ ) & 29.8 & & & & & & $\mathrm{x}$ & & & $\mathrm{x}$ & & & & & $\mathrm{x}$ & \\
\hline${ }^{2} 6 \mathrm{R}-1$ (piece $1,20-23$ ) & 39.4 & $x$ & $\mathrm{x}$ & $\mathrm{x}$ & & & $\mathrm{x}$ & & $\mathrm{x}$ & $x$ & $x$ & $\mathrm{x}$ & & & $\mathrm{x}$ & $x$ \\
\hline${ }^{2} 7 \mathrm{R}-1,2-3$ & 48.7 & & $\mathrm{x}$ & & & & $\mathrm{x}$ & & $x$ & $\mathrm{x}$ & $\mathrm{x}$ & $\mathrm{x}$ & & & $\mathrm{x}$ & $x$ \\
\hline 8R-1 (piece 6, 32-34) & 58.5 & & & & & & $\mathrm{x}$ & & & $\mathrm{x}$ & $\mathrm{x}$ & & & & $\mathrm{x}$ & \\
\hline aR-CC (piece 6, 24-27) & 77.7 & $\mathrm{x}$ & $\mathrm{x}$ & & & $\mathrm{x}$ & $\mathrm{x}$ & $\mathrm{x}$ & & & $\mathrm{x}$ & $\mathrm{x}$ & & & & \\
\hline${ }^{2} 9 \mathrm{R}-\mathrm{CC}$ (piece 7, 28-31) & 77.8 & $\mathrm{x}$ & $\mathrm{x}$ & & & $\mathrm{x}$ & $\mathrm{x}$ & $\mathrm{x}$ & $\mathrm{x}$ & $\mathrm{x}$ & & & & & $\mathrm{x}$ & \\
\hline "10R-CC (piece 4, 22-24) & 82.2 & $\mathrm{x}$ & $\mathrm{x}$ & & & $\mathrm{x}$ & $x$ & & $\mathrm{x}$ & $\mathrm{x}$ & $\mathrm{x}$ & $\mathrm{x}$ & & & & $\mathrm{x}$ \\
\hline "10R-CC (piece 5, 27-29) & 82.3 & $\mathrm{x}$ & $\mathrm{x}$ & & & $x$ & $\mathrm{x}$ & & $\mathrm{x}$ & $\mathrm{x}$ & $\mathrm{x}$ & $\mathrm{x}$ & & & & $\mathrm{x}$ \\
\hline$" 11 R-1,5-7$ & 82.4 & $\mathrm{x}$ & $\ddot{x}$ & & & $\mathrm{x}$ & $\mathrm{x}$ & & $\mathrm{x}$ & $\mathrm{x}$ & & & & & & $x$ \\
\hline $13 \mathrm{R}-1,12-14$ & 98.4 & & & & & & $\mathrm{x}$ & & & $\mathrm{x}$ & & $\mathrm{x}$ & & & & $x$ \\
\hline 13R-CC, $6-7$ & 107.6 & & & & & & $\mathrm{x}$ & & & & & & & & $\mathrm{x}$ & \\
\hline${ }^{a} 13 R-C C$ (piece 4, 6-10) & 107.6 & & & $x$ & $\mathrm{x}$ & $\mathrm{x}$ & $\hat{x}$ & & & & & & & & $x$ & $\mathrm{x}$ \\
\hline \multicolumn{17}{|l|}{$125-779 \mathrm{~A}-$} \\
\hline "9R-1 (piece 7B, 93-94) & 69.0 & & $\mathrm{x}$ & & & & $x$ & & & & & & $\mathrm{x}$ & & & $\mathrm{x}$ \\
\hline${ }^{2} 9 \mathrm{R}-1$ (рiece 7C, 97-99) & 69.1 & & $\mathrm{x}$ & & & & $\mathrm{x}$ & & & & & & $\mathrm{x}$ & & $\mathrm{x}$ & \\
\hline '9R-1, 106-108 & 69.2 & & $\mathrm{x}$ & & & & $\mathrm{x}$ & & & & & & $\mathrm{x}$ & & $\mathrm{x}$ & \\
\hline 30R-1 (piece 10, 100-102) & 246.2 & & & & & & $\mathrm{x}$ & & & & & & & & $x$ & $\mathrm{x}$ \\
\hline 3IR-1 (piece 13, 115-118) & 255.9 & & $\mathrm{x}$ & & & & $\mathrm{x}$ & & & & & & & & $\mathrm{x}$ & \\
\hline${ }^{2} 31 \mathrm{R}-1$ (piece 14, 129-132) & 256.0 & & $\mathrm{x}$ & & & & $\mathrm{x}$ & & & & & & & $\mathrm{x}$ & $\mathrm{x}$ & \\
\hline $31 \mathrm{R}-3$ (piece $1,0-4$ ) & 257.7 & & $\mathrm{x}$ & & & & $x$ & & & & & & & $\mathrm{x}$ & $\mathrm{x}$ & \\
\hline 3IR-CC (piece 7, 61-64) & 264.3 & & $\mathrm{x}$ & & & & $\hat{x}$ & & & & & & $\mathrm{x}$ & $\mathrm{x}$ & $\mathrm{x}$ & \\
\hline
\end{tabular}

metamorphic phase in Samples 125-778A-5R-1 (piece 2, 7-10 cm), 125-778A-6R-1 (piece 1, 20-23 cm), and 125-778A-13R-CC (piece $4,6-10 \mathrm{~cm}$ ) and tends to be replaced by colorless actinolite, consequently showing considerable variation in $\mathrm{Si}$ and $\mathrm{Al}$ contents (Fig. 7). In the rocks from Hole $778 \mathrm{~A}$, actinolite always occurs as replacements after, or overgrowths on, hornblende, and does not coexist with both lawsonite and aragonite.

In Sample 125-778A-13R-CC (piece 4, 6-10 cm), blue amphibole exhibiting a distinct pleochroism from blue to pale violet can be seen along the rims or cleavage traces of relict actinolitized hornblendes (Fig. 1A). Where both actinolite and blue amphibole are present, the latter always rims the former, and it appears that the two phases were not in equilibrium. Blue amphibole is also found as interstitial fillings of some pull-apart relict hornblendes, which suggests syntectonic recrystallization. $\mathrm{FeO}$ and $\mathrm{Fe}_{2} \mathrm{O}_{3}$ for blue amphibole were calculated using the model: $\mathrm{Fe}^{2+}+\mathrm{Fe}^{3+}+\mathrm{Mg}+\mathrm{Mn}+\mathrm{Al}+\mathrm{Ti}+\mathrm{Si}=$ $13, \mathrm{O}=23$. Microprobe analyses indicate that the amphibole is a solid solution between actinolite and magnesioriebeckite (Table 4; Fig. 8), and can be classified as winchite after Leake (1978). This kind of winchite favors high pressure conditions in comparison with actinolite (Otsuki and Banno, 1990). Although metamorphic rocks in Hole 778A occur as tectonic fragments highly displaced from their original positions within a serpentinite matrix, those metamorphic rocks recovered from cores within several tens of meters do not significantly differ from each other in type and grade of metamorphism. This may suggest that the tectonic displacement among various types of metamorphic fragments did not take place in such a small-scale domain. Therefore, taking into account the associated lawsonite- and aragonite-bearing fragments, winchite probably recrystallized at the same metamorphic event during which lawsonite and aragonite were formed.

\section{Sodic Pyroxene}

Sodic pyroxene is found as tiny spherical aggregates of acicular crystals in plagioclase phenocrysts pseudomorphosed by albite and pumpellyite and as epitaxial fringes along the cleavage traces of igneous clinopyroxene. It was confirmed by using X-ray diffraction. Sodic pyroxene usually coexists with pumpellyite and quartz, but does not coexist with lawsonite. Representative analyses of sodic pyroxene are given in Table $5 . \mathrm{FeO}$ and $\mathrm{Fe}_{2} \mathrm{O}_{3}$ were calculated using the model: $\mathrm{Na}+\mathrm{Ca}+\mathrm{K}+\mathrm{Mg}+\mathrm{Mn}+\mathrm{Fe}^{2+}+\mathrm{Fe}^{3+}+\mathrm{Al}+\mathrm{Ti}+\mathrm{Si}=4$, $\mathrm{O}=6$. Their end-member components were calculated using the method of Banno (1959). Most analyzed sodic pyroxenes are scattered around the chloromelanite field in Figure 9 and contain $30 \%-$ $35 \%$ of the jadeite molecule. Sodic pyroxenes in Sample 125-778 A-13R-CC (piece 4, 6-10 cm) are aegirine-augite and contain about $60 \%$ of the acmite molecule and less than $2 \%$ of the jadeite molecule (Table 5; Fig. 9). This rock contains hematite and lacks quartz. The high proportion of the acmite molecule may result in part from its silica-deficient composition and from the high oxidation state of this rock during metamorphism.

\section{Aragonite}

Aragonite was identified in Hole 778A rocks under the microscope using sections stained with Feigl's solution by the method of Gouchi and Banno (1974), and for type specimens was confirmed by using $\mathrm{X}$-ray diffraction. Aragonite was replaced by calcite along irregular cleavages and was observed as small discrete crystals with identical optical orientations within calcite pools (Fig. 1C). Aragonite exhibits a slightly higher refractive index than calcite. Because metamorphic aragonite is coarse-grained and coexists with lawsonite and/or pum- 
Table 1 (continued).

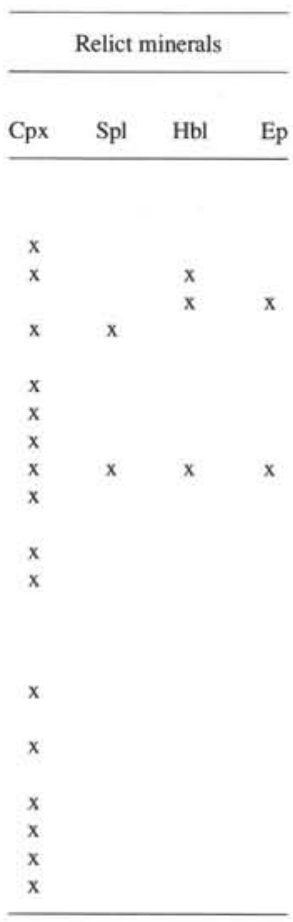

pellyite, it is different from the fine-grained authigenic aragonite that has been reported from the surface of this seamount as a hydrothermal product (Haggerty, 1987).

\section{Phengite}

Fine-grained aggregates of phengite are found in association with lawsonite as vein minerals in Samples 125-778A-9R-CC (piece 6, $24-27 \mathrm{~cm}$ ) and 125-778A-9R-CC (piece 7, 28-31 cm). Phengite contains about 60 to $75 \mathrm{~mol} \%$ of the celadonite component, which is comparable to that reported from the Franciscan pumpellyite zone metabasites at Cazadero area (Maruyama and Liou, 1987) (Table 6; Fig. 10).

\section{Garnet}

Framboidal garnet occurs in association with chlorite, pumpellyite, and zeolite as a vein mineral in Samples 125-779A-31R-1 (piece 14, 129-132 cm) and 31R-CC (piece 7, 61- $64 \mathrm{~cm}$ ). Analyzed garnets characteristically contain 5 to $6.5 \mathrm{wt} \%$ of $\mathrm{TiO}_{2}$ (Table 7) and have compositions between Ti-rich andradite (melanite) and hydrogrossular.

\section{Zeolites}

Zeolites, occurring as vein minerals in the rocks from Hole 779A, were identified optically and by X-ray diffraction. Most are natrolite, but thomsonite (Table 7) was found in Sample 125-779A-9R-1 (piece 7B, 93-94 cm). Zeolite veins are usually accompanied by pumpellyite, but some zeolite veins cut pumpellyite veins.

\section{Other Minerals}

Chlorite is ubiquitous in varying amounts in the rocks from Holes $778 \mathrm{~A}$ and $779 \mathrm{~A}$. The chlorites show a small range in $\mathrm{Al} /(\mathrm{Fe}+\mathrm{Mg})$, but have an appreciable range in $\mathrm{Fe} / \mathrm{Mg}$, reflecting variations in host rock composition. Representative microprobe analyses of chlorite are given in Tables 6 and 7.

Table 2. Representative analyses of lawsonite, Hole 778A.

\begin{tabular}{|c|c|c|c|c|c|c|c|c|}
\hline \multirow[t]{2}{*}{ Sample 125-778A- } & \multicolumn{3}{|c|}{$6 \mathrm{R}-1$} & \multicolumn{2}{|c|}{ 9R-CC } & \multirow{2}{*}{$\frac{10 \mathrm{R}-\mathrm{CC}}{\text { Piece } 4}$} & \multicolumn{2}{|c|}{$11 \mathrm{R}-1$} \\
\hline & Piece 1 & Piece 1 & Piece 1 & Piece 7 & Piece 7 & & $5-7 \mathrm{~cm}$ & $5-7 \mathrm{~cm}$ \\
\hline $\mathrm{SiO}_{2}$ & 36.28 & 36.53 & 36.88 & 37.89 & 36.63 & 36.67 & 37.00 & 36.34 \\
\hline $\mathrm{TiO}_{2}$ & 0.05 & 0.03 & 0.06 & 0.11 & 0.07 & 0.06 & 0.25 & 0.19 \\
\hline $\mathrm{Al}_{2} \mathrm{O}_{3}$ & 27.16 & 27.03 & 30.10 & 28.77 & 27.72 & 29.32 & 29.97 & 28.94 \\
\hline $\mathrm{Fe}_{2} \mathrm{O}_{3}^{* *}$ & 7.26 & 6.20 & 2.62 & 4.65 & 3.06 & 2.91 & 1.54 & 3.29 \\
\hline $\mathrm{MnO}$ & 0.12 & 0.08 & 0.07 & 0.13 & 0.22 & 0.06 & 0.29 & 0.12 \\
\hline $\mathrm{MgO}$ & 0.00 & 0.00 & 0.00 & 0.19 & 0.75 & 0.00 & 0.00 & 0.15 \\
\hline $\mathrm{CaO}$ & 17.17 & 17.21 & 17.28 & 17.19 & 17.89 & 17.21 & 17.53 & 16.81 \\
\hline $\mathrm{Na}_{2} \mathrm{O}$ & 0.00 & 0.00 & 0.00 & 0.00 & 0.00 & 0.00 & 0.00 & 0.00 \\
\hline $\mathrm{K}_{2} \mathrm{O}$ & 0.03 & 0.04 & 0.04 & 0.02 & 0.25 & 0.05 & 0.05 & 0.04 \\
\hline \multirow[t]{2}{*}{ Total } & 88.07 & 87.12 & 87.05 & 88.95 & 86.59 & 86.28 & 86.63 & 85.78 \\
\hline & $\mathrm{O}=8$ & & & & & & & \\
\hline $\mathrm{Si}$ & 1.970 & 1.996 & 1.985 & 2.009 & 2.001 & 1.995 & 1.998 & 1.991 \\
\hline $\mathrm{Ti}$ & 0.002 & 0.001 & 0.002 & 0.004 & 0.003 & 0.002 & 0.010 & 0.008 \\
\hline $\mathrm{Al}$ & 1.738 & 1.741 & 1.910 & 1.798 & 1.785 & 1.880 & 1.907 & 1.868 \\
\hline $\mathrm{Fe}^{3+}$ & 0.296 & 0.255 & 0.106 & 0.185 & 0.126 & 0.119 & 0.063 & 0.136 \\
\hline $\mathrm{Mn}$ & 0.006 & 0.004 & 0.003 & 0.006 & 0.010 & 0.003 & 0.013 & 0.006 \\
\hline $\mathrm{Mg}$ & 0.000 & 0.000 & 0.000 & 0.015 & 0.061 & 0.000 & 0.000 & 0.004 \\
\hline $\mathrm{Ca}$ & 0.999 & 1.007 & 0.997 & 0.977 & 1.047 & 1.003 & 1.014 & 0.987 \\
\hline $\mathrm{Na}$ & 0.000 & 0.000 & 0.000 & 0.000 & 0.000 & 0.000 & 0.000 & 0.000 \\
\hline K & 0.002 & 0.003 & 0.003 & 0.001 & 0.017 & 0.003 & 0.003 & 0.003 \\
\hline Sum & 5.013 & 5.007 & 5.006 & 4.995 & 5.050 & 5.005 & 5.008 & 5.003 \\
\hline
\end{tabular}

Note: Total $\mathrm{Fe}$ as $\mathrm{Fe}_{2} \mathrm{O}_{3}{ }^{* *}$. 


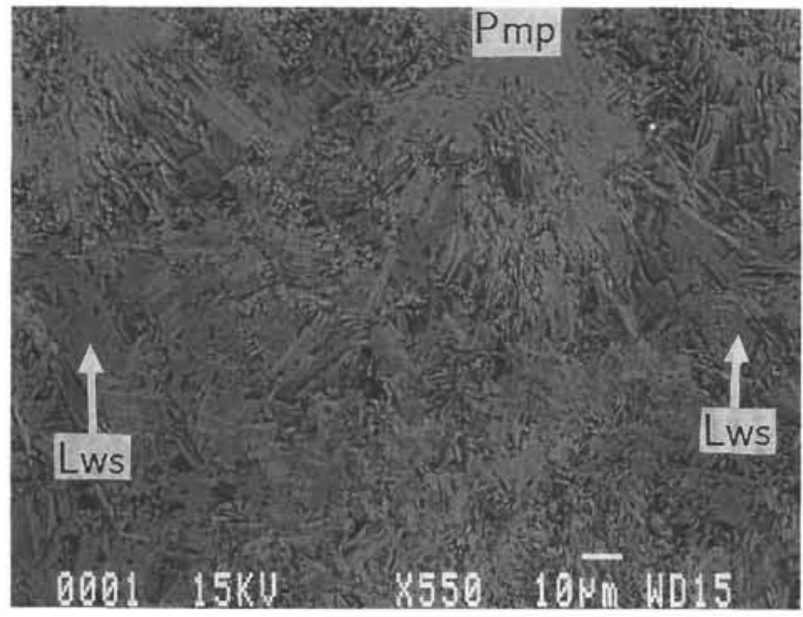

A

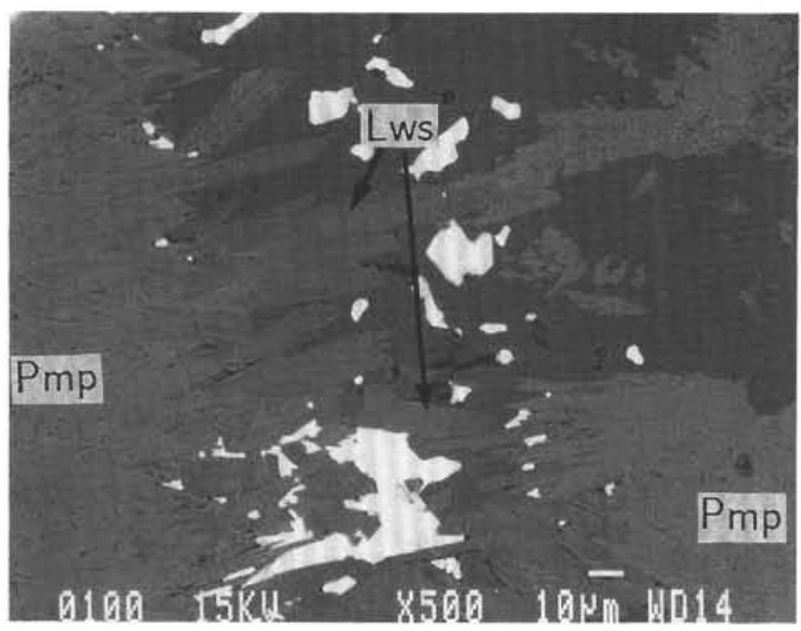

C

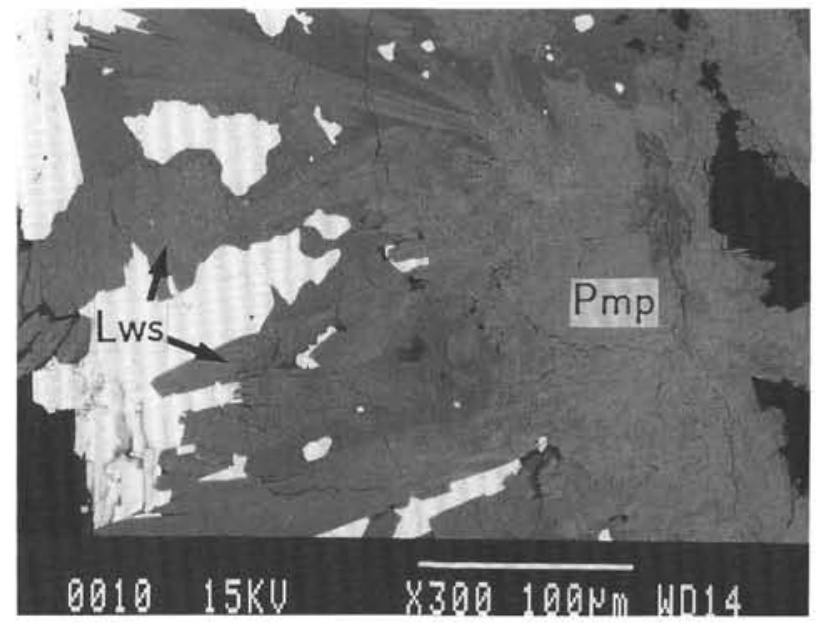

B

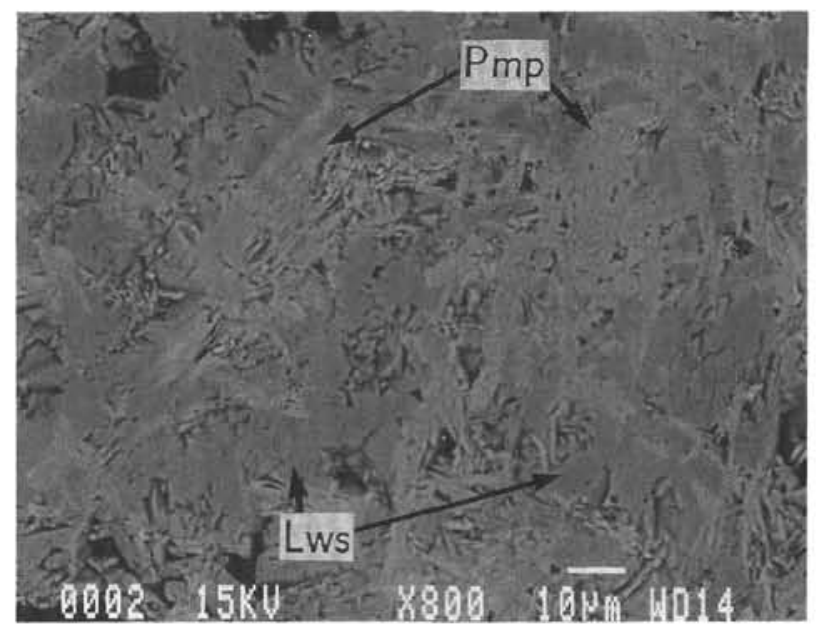

D

Figure 3. Back-scattered images showing relationships between pumpellyite and lawsonite. Each image corresponds to a part of each photomicrograph with the same labels $\mathrm{A}-\mathrm{D}$ in Figure 1. Bright portions in $\mathrm{B}$ and $\mathrm{C}$ are due to staining $(\mathrm{Ag})$ for aragonite.

Quartz occurs as a vein mineral in association with aragonite, pumpellyite, and lawsonite in Hole 778A.

Albite is found as a vein mineral or replacing primary plagioclase in the rocks from Hole 778A. Albite shows a narrow range of composition, with An of less than $2 \%$ and Or of less than $1 \%$ (Table 6).

Sphene is an accessory, but ubiquitous, mineral in all the rocks described here. It is found as dusty aggregates or as tiny anhedral grains scattered in the matrix and in veins. Representative chemical compositions are given in Tables 6 and 7. Sphene contains appreciable amounts of $\mathrm{FeO}(2-3 \mathrm{wt} \%)$ and $\mathrm{Al}_{2} \mathrm{O}_{3}(3.5-5 \mathrm{wt} \%)$.

Opaque minerals include magnetite, ilmenite, hematite, and pyrite. Hematite and magnetite occur mainly as replacements of primary chromian spinel in the matrix and as fine-grained euhedral to subhedral crystals in both matrix and vein. In the former case, these minerals contain variable amounts of $\mathrm{Cr}_{2} \mathrm{O}_{3}$.

Epidote is found as detrital grains in Sample 125-778A-6R-1 (piece $1,20-23 \mathrm{~cm}$ ). $\mathrm{Fe}^{3+} / \mathrm{Al}$ ratios of epidote range from 0.16 to 0.26 (Fig. 11).

\section{HOLES 783A AND 784B ("TORISHIMA FOREARC SEAMOUNT')}

\section{Petrographical Descriptions}

Two sites (Sites 783 and 784) were drilled on the flanks of Torishima Forearc Seamount, which is located east of Torishima in the Izu-Ogasawara forearc, about $40 \mathrm{~km}$ west of the trench axis. Metamorphic rocks were found as 2- to $5-\mathrm{cm}$ subrounded clasts in the serpentinite matrix from Holes 783A and 784A; the numbers of samples exceeded 4 and 10, respectively. Four clasts from Hole 783A and eight from Hole 784A were examined; these are predominantly fractured and fragmented metabasalts, the protoliths of which appear to be similar to those from Holes 778 A and 779A. Samples 125-784A$40 \mathrm{R}-1,12-15 \mathrm{~cm}$, and $125-784 \mathrm{~A} 40 \mathrm{R}-1,13-15 \mathrm{~cm}$, exhibit typical textures of fracturing and fragmentation (Fig. 12A). Metabasalts from Holes 783A and 784A do not significantly differ from each other, either in metamorphic phases or mineral assemblages. They contain the metamorphic minerals epidote, prehnite, actinolite, sphene, quartz, zeolites, and albite (Table 8). 


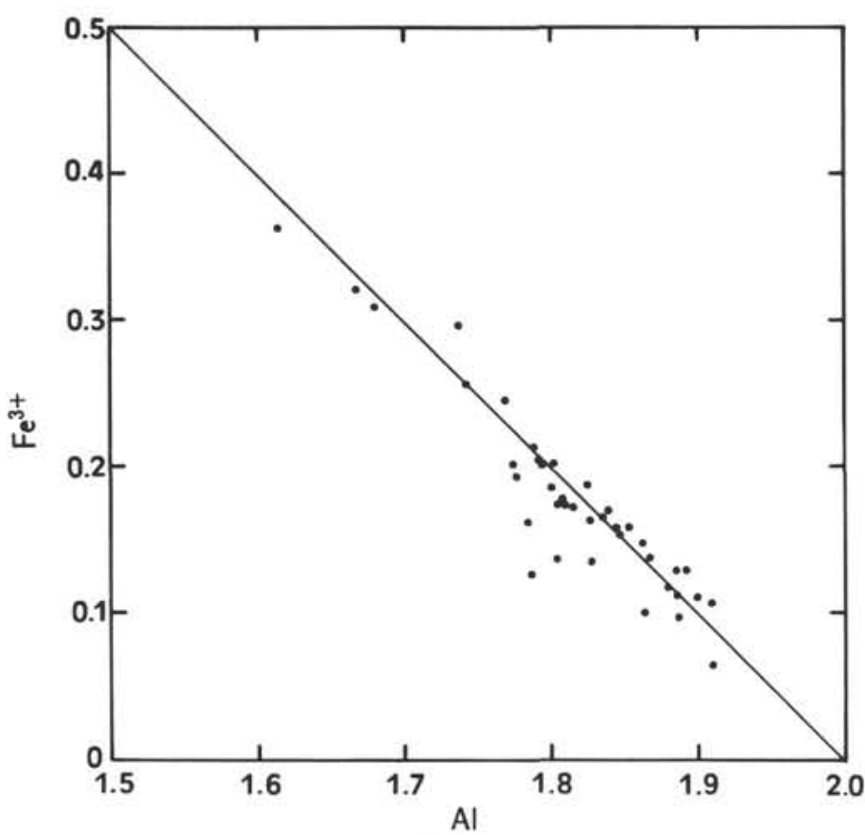

Figure 4. Chemical compositions of lawsonite on an $\mathrm{Al}$ vs. $\mathrm{Fe}^{3+}$ diagram showing significant $\mathrm{Fe}^{3+}$ substitution for $\mathrm{Al}$ in lawsonite.

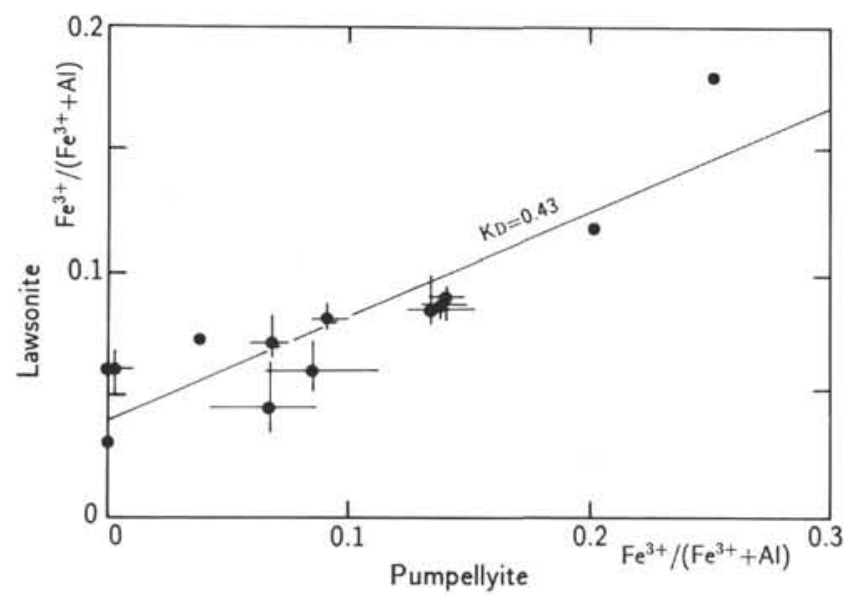

Figure $5 . \mathrm{Fe}^{3+}$-Al partitioning between lawsonite and pumpellyite. Vertical and horizontal bars represent the ranges of compositional variations in $\mathrm{Fe}^{3+} / \mathrm{Al}$ ratio of lawsonite and pumpellyite, respectively.

Sample 125-784A-39R-1, 5-6 cm, contains metamorphic clasts up to $1.5 \mathrm{~mm}$ in diameter in a dusty matrix. These clasts are composed of green homblende, albite, sphene, and dusty clay minerals.

\section{Mineralogy}

The following is a brief description of main metamorphic minerals, epidote, actinolite, prehnite, and others in the rocks from Holes $783 \mathrm{~A}$ and $784 \mathrm{~A}$. Representative chemical compositions of these metamorphic minerals from Holes $783 \mathrm{~A}$ and $784 \mathrm{~A}$ are given in Tables 9 and 10, respectively.

\section{Epidote}

Epidote (Tables 9 and 10) replaces primary plagioclase and forms small anhedral grains scattered throughout the matrix. The $\mathrm{Fe}^{3+} / \mathrm{Al}$ ratios of epidote range from 0.05 to 0.36 (Fig. 11). Epidotes replacing

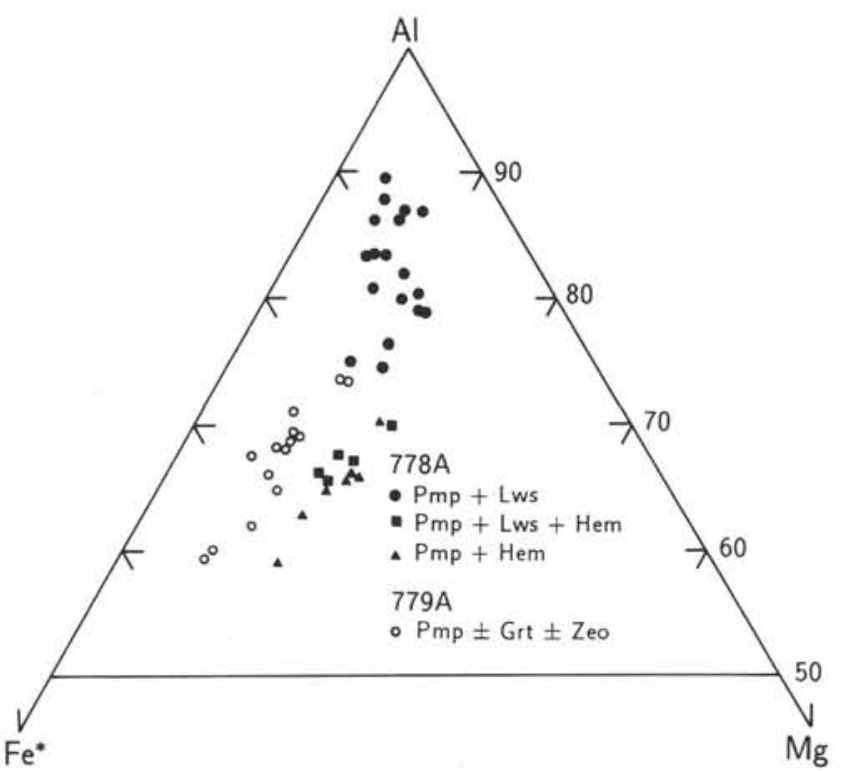

Figure 6. Chemical compositions of pumpellyite on $\mathrm{Al}-\mathrm{Fe} *-\mathrm{Mg}$ diagram. Pmp $=$ pumpellyite, Lws $=$ lawsonite, $\mathrm{Hem}=$ hematite, $\mathrm{Grt}=$ garnet, $\mathrm{Zeo}=$ zeolite .

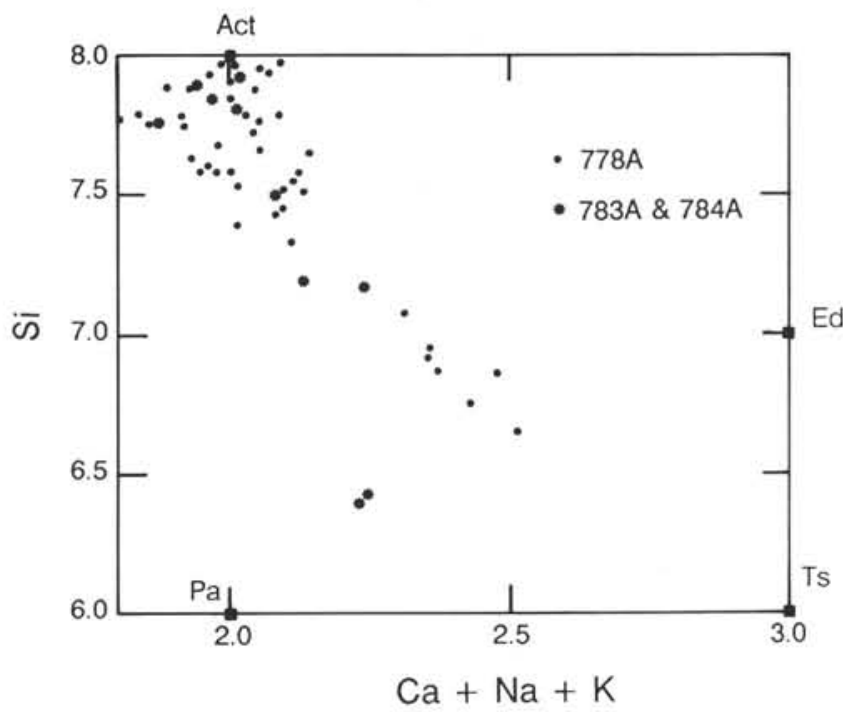

Figure 7. $\mathrm{Ca}+\mathrm{Na}+\mathrm{K}$ vs. Si plot of $\mathrm{Ca}$-amphiboles.

plagioclase appear to have lower $\mathrm{Fe}^{3+} / \mathrm{Al}$ ratios than those in the matrix, reflecting the local chemical composition.

\section{Actinolite}

Colorless actinolite (Tables 9 and 10) occurs both as overgrowths on, and pseudomorphs after, clinopyroxene and hornblende, and as aggregates of tiny acicular crystals in the matrix (Fig. 12B). Microprobe analyses indicate that actinolites contain less than $2 \mathrm{wt} \%$ $\mathrm{Al}_{2} \mathrm{O}_{3}$, and are close to the actinolite end-member composition.

\section{Prehnite}

Prehnite (Tables 9 and 10) occurs as distinct euhedral crystals or tabular masses in veins and as fine-grained aggregates after primary 


\section{H. MAEKAWAET AL.}

Table 3. Representative analyses of pumpellyite, Holes 778A and 779A.

\begin{tabular}{|c|c|c|c|c|c|c|c|c|c|c|c|}
\hline \multirow[t]{2}{*}{ Sample } & \multicolumn{2}{|c|}{$125-778-6 \mathrm{R}-1$} & \multicolumn{2}{|c|}{$125-778 \mathrm{~A}-7 \mathrm{R}-1$} & \multicolumn{2}{|c|}{ 125-778A-9R-CC } & \multirow{2}{*}{$\frac{125-778 \mathrm{~A}-10 \mathrm{R}-\mathrm{CC}}{\text { Piece } 4^{\mathrm{a}}}$} & \multicolumn{2}{|c|}{$125-779 \mathrm{~A}-9 \mathrm{R}-1$} & \multicolumn{2}{|c|}{$125-779 A-9 R-1$} \\
\hline & Piece $1^{a}$ & Piece $1^{b}$ & $2-3 \mathrm{~cm}^{\mathrm{a}}$ & $2-3 \mathrm{~cm}^{\mathrm{b}}$ & Piece $6^{a}$ & Piece $6^{b}$ & & Piece $7 \mathrm{~B}^{\mathrm{a}}$ & Piece $7 B^{b}$ & Piece $7 C^{a}$ & Piece $7 C^{b}$ \\
\hline $\mathrm{SiO}_{2}$ & 35.91 & & 35.36 & & 36.87 & & 35.92 & 36.66 & & 36.34 & \\
\hline $\mathrm{TiO}_{2}$ & 0.04 & & 0.05 & & 0.04 & & 0.04 & 0.03 & & 0.09 & \\
\hline $\mathrm{Al}_{2} \mathrm{O}_{3}$ & 21.45 & & 17.43 & & 24.68 & & 26.95 & 20.86 & & 20.32 & \\
\hline $\mathrm{Fe}_{2} \mathrm{O}_{3}$ & & 6.32 & & 10.95 & & 1.96 & & & 7.20 & & 8.40 \\
\hline $\mathrm{FeO}$ & 7.76 & 2.08 & 12.26 & 2.41 & 4.12 & 2.36 & 3.15 & 10.68 & 4.20 & 11.70 & 4.14 \\
\hline $\mathrm{MnO}$ & 0.32 & & 0.16 & & 0.27 & & 0.59 & 0.28 & & 0.30 & \\
\hline $\mathrm{MgO}$ & 2.85 & & 2.58 & & 2.79 & & 1.01 & 1.73 & & 1.75 & \\
\hline $\mathrm{CaO}$ & 21.88 & & 22.01 & & 22.59 & & 21.58 & 22.84 & & 22.56 & \\
\hline $\mathrm{Na}_{2} \mathrm{O}$ & 0.00 & & 0.00 & & 0.05 & & 0.44 & 0.00 & & 0.00 & \\
\hline $\mathrm{K}_{2} \mathrm{O}$ & 0.01 & & 0.03 & & 0.06 & & 0.06 & 0.06 & & 0.05 & \\
\hline Total & 90.22 & 90.86 & 89.88 & 90.98 & 91.47 & 91.67 & 89.74 & 93.14 & 93.86 & 93.11 & 93.95 \\
\hline & $\mathrm{O}=24.5$ & & & & & & & & & & \\
\hline $\mathrm{Si}$ & 6.099 & 6.000 & 6.213 & 6.034 & 6.040 & 6.010 & 5.955 & 6.131 & 6.019 & 6.115 & 5.985 \\
\hline $\mathrm{Ti}$ & 0.005 & 0.005 & 0.007 & 0.006 & 0.005 & 0.005 & 0.005 & 0.004 & 0.004 & 0.011 & 0.011 \\
\hline $\mathrm{Al}_{2}$ & 4.293 & 4.224 & 3.609 & 3.506 & 4.765 & 4.742 & 5.266 & 4.111 & 4.037 & 4.030 & 3.944 \\
\hline $\mathrm{Fe}^{3+}$ & & 0.794 & & 1.406 & & 0.240 & & & 0.890 & & 1.041 \\
\hline $\mathrm{Fe}^{2+}$ & 1.102 & 0.290 & 1.801 & 0.344 & 0.564 & 0.322 & 0.437 & 1.494 & 0.577 & 1.647 & 0.570 \\
\hline Mn & 0.046 & 0.045 & 0.024 & 0.023 & 0.037 & 0.037 & 0.083 & 0.040 & 0.039 & 0.043 & 0.042 \\
\hline $\mathrm{Mg}$ & 0.722 & 0.710 & 0.676 & 0.656 & 0.681 & 0.678 & 0.250 & 0.431 & 0.423 & 0.439 & 0.430 \\
\hline $\mathrm{Ca}$ & 3.981 & 3.917 & 4.143 & 4.024 & 3.965 & 3.946 & 3.834 & 4.093 & 4.018 & 4.068 & 3.981 \\
\hline $\mathrm{Na}$ & 0.000 & 0.000 & 0.000 & 0.000 & 0.016 & 0.016 & 0.141 & 0.000 & 0.000 & 0.000 & 0.000 \\
\hline K & 0.002 & 0.002 & 0.007 & 0.007 & 0.013 & 0.012 & 0.013 & 0.013 & 0.013 & 0.011 & 0.011 \\
\hline Sum & 16.250 & 15.987 & 16.480 & 16.006 & 16.086 & 16.008 & 15.984 & 16.317 & 16.020 & 16.364 & 16.015 \\
\hline
\end{tabular}

Total $\mathrm{Fe}$ as $\mathrm{FeO}$.

${ }^{b} \mathrm{Fe}^{3+}$ and $\mathrm{Fe}^{2+}$ were calculated according to formula constraints.

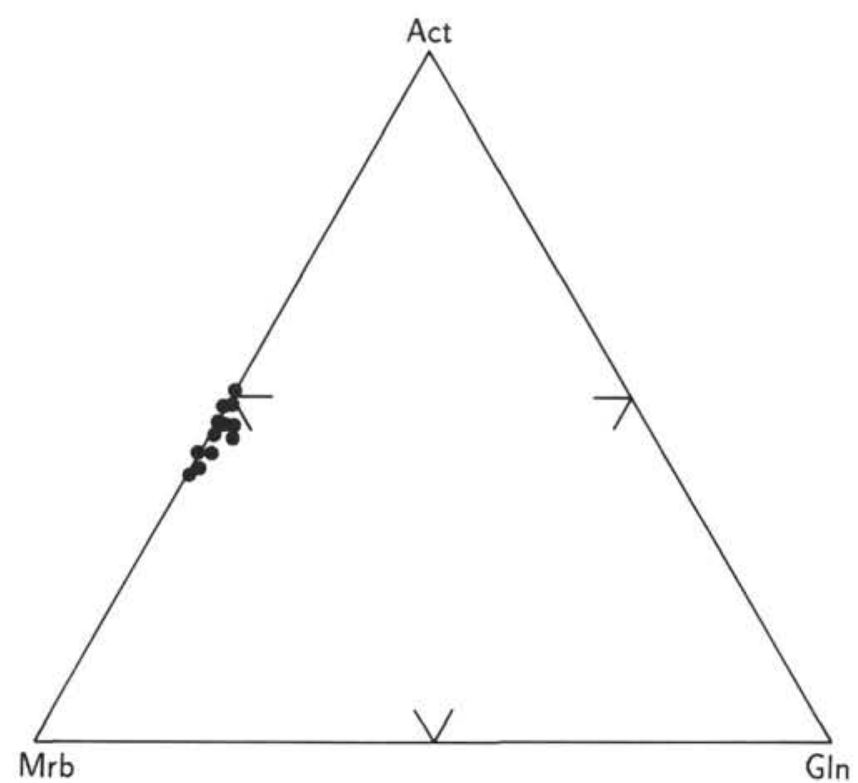

Figure 8. Chemical compositions of winchite on actinolite (Act)-magnesioriebeckite (Mrb)-glaucophane (GIn) triangular diagram.

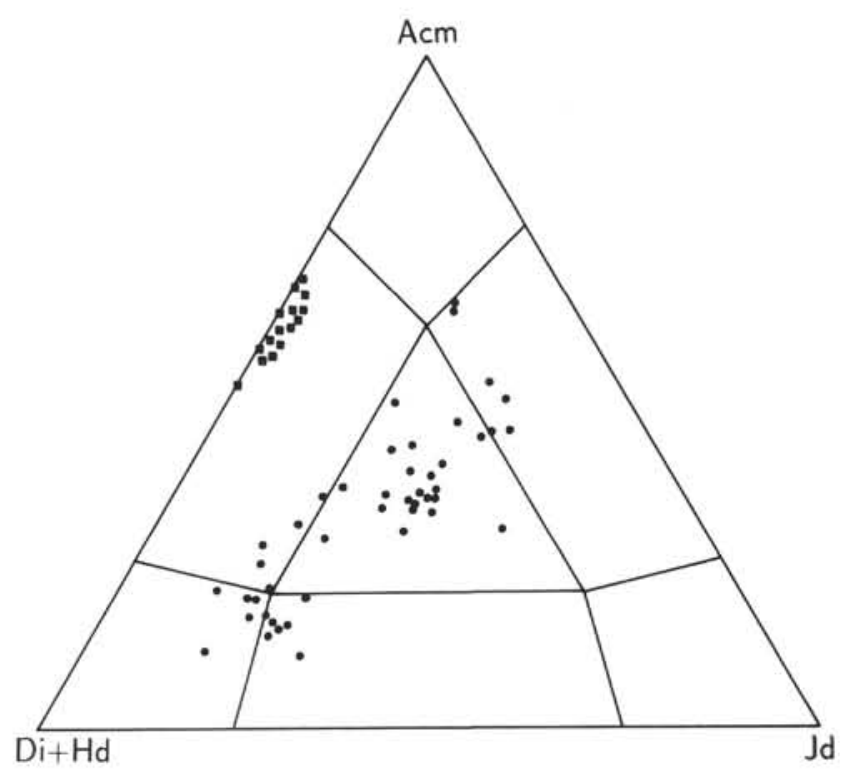

Figure 9. Chemical compositions of sodic pyroxene on jadeite (Jd)-diopside + hedenbergite (Di + Hd)-acmite (Acm) diagram. Solid squares: Sample 125-778A-13R-CC (piece 4, 6-10 cm). 
Table 3 (continued).

\begin{tabular}{|c|c|c|}
\hline \multirow[t]{2}{*}{ Sample } & \multicolumn{2}{|c|}{ 125-779A-31R-1 } \\
\hline & Piece $13^{2}$ & Piece $13^{b}$ \\
\hline $\mathrm{SiO}_{2}$ & 34.62 & \\
\hline $\mathrm{TiO}_{2}$ & 0.02 & \\
\hline $\mathrm{Al}_{2} \mathrm{O}_{3}$ & 17.11 & \\
\hline $\mathrm{Fe}_{2} \mathrm{O}_{3}$ & & 10.52 \\
\hline $\mathrm{FeO}$ & 13.94 & 4.48 \\
\hline $\mathrm{MnO}$ & 0.04 & \\
\hline $\mathrm{MgO}$ & 1.34 & \\
\hline $\mathrm{CaO}$ & 21.86 & \\
\hline $\mathrm{Na}_{2} \mathrm{O}$ & 0.00 & \\
\hline $\mathrm{K}_{2} \mathrm{O}$ & 0.07 & \\
\hline Total & 89.00 & 90.06 \\
\hline $\mathrm{Si}$ & 6.206 & 6.031 \\
\hline $\mathrm{Ti}$ & 0.003 & 0.003 \\
\hline $\mathrm{Al}$ & 3.615 & 3.513 \\
\hline $\mathrm{Fe}^{3+}$ & & 1.379 \\
\hline $\mathrm{Fe}^{2+}$ & 2.090 & 0.652 \\
\hline Mn & 0.006 & 0.006 \\
\hline $\mathrm{Mg}$ & 0.358 & 0.348 \\
\hline $\mathrm{Ca}$ & 4.199 & 4.080 \\
\hline $\mathrm{Na}$ & 0.000 & 0.000 \\
\hline K & 0.016 & 0.016 \\
\hline Sum & 16.493 & 16.028 \\
\hline
\end{tabular}

plagioclase (Fig. 12B). $\mathrm{Fe}_{2} \mathrm{O}_{3}$ contents of prehnite are less than 1.5 wt $\%$, which is low in comparison with Hole 504B near the Costa Rica Rift, where actinolite, epidote, and prehnite coexist (Ishizuka, 1989).

\section{Other Minerals}

Chlorite (Tables 9 and 10) is common in the rocks from Holes $783 \mathrm{~A}$ and $784 \mathrm{~A}$. It is found in veins and vesicles, as replacements after glassy matrices, and in primary igneous phases, such as clinopyroxene, olivine, and plagioclase.

Veins of natrolite and clay were found in Sample 125-783A-18R$1,0-3 \mathrm{~cm}$. They are probably late-stage alteration products. Sphene is ubiquitous as dusty, fine-grained aggregates in both veins and in the matrix. Albite and quartz, showing conspicuous wavy-extinction, occur in some samples as distinct individual grains in the matrix.

\section{DISCUSSION}

\section{Mineral Paragenesis and Metamorphic Conditions}

\section{Hole 778 A}

The mineral paragenesis of the rocks from Hole 778A is graphically represented in Figure 13, where each phase is projected from constant subassemblages (quartz + albite + chlorite + fluids) onto the $\mathrm{Ca}-\mathrm{Fe}^{3+}-\mathrm{AFM}\left(2 \mathrm{Al} \cdot \mathrm{Fe}^{2+} / \mathrm{Mg}\right)$ plane, which is normal to the $\mathrm{Ca}-2 \mathrm{Al}-$ $\mathrm{Fe}^{2+} / \mathrm{Mg}$ base and is inclined $80^{\circ}$ to the $2 \mathrm{Al}-\mathrm{Ca}$ junction in the $\mathrm{Ca}-2 \mathrm{Al}-2 \mathrm{Fe}^{3+}-\mathrm{Fe}^{2+} / \mathrm{Mg}$ tetrahedron (Maruyama et al., 1986). The projection method is that described by Greenwood (1975). The projection matrix used in the construction of the diagram is given in Table 11. To evaluate the effect of $\mathrm{Fe}^{3+}$ substitution for $\mathrm{Al}$ in $\mathrm{Ca}-\mathrm{Al}$ silicates, the region between the $2 \mathrm{Fe}^{3+}$ apex and the $\mathrm{Ca}-\mathrm{AFM}$ junction is exaggerated to make the angle $2 \mathrm{Fe}^{3+}-\mathrm{AFM}-\mathrm{Ca}$ become $60^{\circ}$. In Figure 13, the phase relations of the winchite- and sodic pyroxenebearing rock are unreliable because the rock lacks quartz.

Table 4. Representative analyses of winchite and Ca-amphiboles of Sample 125-778A-13R-CC (piece 4, 6-10 cm).

\begin{tabular}{|c|c|c|c|c|c|c|c|c|}
\hline Mineral & Winchite $^{a}$ & Winchite ${ }^{a}$ & Winchite & Homblende $^{b}$ & Homblende $^{b}$ & Homblende $^{b}$ & Actinolite $^{\mathrm{b}}$ & Actinolite $^{b}$ \\
\hline $\mathrm{SiO}_{2}$ & 56.64 & 56.28 & 57.01 & 47.78 & 48.69 & 52.19 & 57,48 & 56.77 \\
\hline $\mathrm{TiO}_{2}$ & 0.03 & 0.03 & 0.03 & 0.09 & 0.79 & 0.27 & 0.13 & 0.06 \\
\hline $\mathrm{Al}_{2} \mathrm{O}_{3}$ & 0.26 & 0.35 & 0.34 & 9.14 & 7.89 & 4.06 & 0.00 & 0.90 \\
\hline $\mathrm{Fe}_{2} \mathrm{O}_{3}$ & 10.93 & 12.35 & 10.18 & & & & & \\
\hline $\mathrm{FeO}$ & 5.38 & 4.83 & 5.33 & 6.53 & 6.69 & 10.90 & 3.78 & 2.27 \\
\hline $\mathrm{MnO}$ & 0.61 & 0.64 & 0.55 & 0.10 & 0.20 & 0.30 & 0.20 & 0.23 \\
\hline $\mathrm{MgO}$ & 14.72 & 14.20 & 15.16 & 18.52 & 17.53 & 17.82 & 21.98 & 22.99 \\
\hline $\mathrm{CaO}$ & 5.54 & 4.98 & 5.94 & 12.75 & 12.62 & 12.07 & 13.32 & 13.04 \\
\hline $\mathrm{Na}_{2} \mathrm{O}$ & 4.14 & 4.22 & 3.92 & 1.79 & 1.25 & 0.73 & 0.00 & 0.15 \\
\hline $\mathrm{K}_{2} \mathrm{O}$ & 0.03 & 0.01 & 0.02 & 0.07 & 0.03 & 0.11 & 0.02 & 0.04 \\
\hline \multirow[t]{2}{*}{ Total } & 98.28 & 97.89 & 98.48 & 96.77 & 95.69 & 98.45 & 96.91 & 96.45 \\
\hline & $\mathrm{O}=23$ & & & & & & & \\
\hline $\mathrm{Si}$ & 7.991 & 7.974 & 8.002 & 6.849 & 7.035 & 7.428 & 7.987 & 7.893 \\
\hline Ti & 0.003 & 0.004 & 0.003 & 0.010 & 0.086 & 0.029 & 0.013 & 0.006 \\
\hline $\mathrm{Al}$ & 0.043 & 0.058 & 0.056 & 1.544 & 1.345 & 0.681 & 0.000 & 0.148 \\
\hline $\mathrm{Fe}^{3+}$ & 1.160 & 1.317 & 1.076 & & & & & \\
\hline $\mathrm{Fe}^{2+}$ & 0.635 & 0.572 & 0.626 & 0.783 & 0.808 & 1.297 & 0.439 & 0.264 \\
\hline Mn & 0.073 & 0.077 & 0.065 & 0.013 & 0.025 & 0.036 & 0.023 & 0.027 \\
\hline $\mathrm{Mg}$ & 3.095 & 2.999 & 3.172 & 3.956 & 3.776 & 3.781 & 4.553 & 4.724 \\
\hline $\mathrm{Ca}$ & 0.837 & 0.755 & 0.893 & 1.959 & 1.954 & 1.841 & 1.983 & 1.943 \\
\hline $\mathrm{Na}$ & 1.131 & 1.159 & 1.068 & 0.497 & 0.351 & 0.203 & 0.000 & 0.040 \\
\hline $\mathrm{K}$ & 0.005 & 0.002 & 0.004 & 0.013 & 0.006 & 0.020 & 0.004 & 0.006 \\
\hline Sum & 14.973 & 14.917 & 14.965 & 15.624 & 15.386 & 15.316 & 15.002 & 15.051 \\
\hline
\end{tabular}

${ }^{\mathrm{a}} \mathrm{Fe}^{3+}$ and $\mathrm{Fe}^{2+}$ of winchite were calculated according to formula constraints.

b Total $\mathrm{Fe}$ as $\mathrm{FeO}$. 
Table 5. Representative analyses of sodic pyroxene and relict pyroxene, Hole 778A.

\begin{tabular}{|c|c|c|c|c|c|c|c|c|c|}
\hline \multirow{2}{*}{$\begin{array}{l}\text { Mineral } \\
\text { Sample 125-778A- }\end{array}$} & \multicolumn{7}{|c|}{ Sodic pyroxene ${ }^{\mathrm{a}}$} & \multicolumn{2}{|c|}{ Relict pyroxene ${ }^{b}$} \\
\hline & $\begin{array}{c}\text { 10R-CC } \\
\text { Piece } 4\end{array}$ & $\begin{array}{l}\text { 10R-CC } \\
\text { Piece } 4\end{array}$ & $\begin{array}{l}\text { 10R-CC } \\
\text { Piece } 4\end{array}$ & $\begin{array}{l}\text { 10R-CC } \\
\text { Piece } 5\end{array}$ & $\begin{array}{c}11 \mathrm{R}-1 \\
\text { Piece } 7\end{array}$ & $\begin{array}{l}\text { 13R-CC } \\
\text { Piece } 4\end{array}$ & $\begin{array}{l}\text { 13R-CC } \\
\text { Piece } 4\end{array}$ & $\begin{array}{l}\text { 13R-CC } \\
\text { Piece } 4\end{array}$ & $\begin{array}{l}\text { 13R-CC } \\
\text { Piece } 4\end{array}$ \\
\hline $\mathrm{SiO}_{2}$ & 52.38 & 52.53 & 51.93 & 51.92 & 53.28 & 52.62 & 51.36 & 52.91 & 52.82 \\
\hline $\mathrm{TiO}_{2}^{2}$ & 0.30 & 0.26 & 0.25 & 0.37 & 0.41 & 0.12 & 0.11 & 0.10 & 0.07 \\
\hline $\mathrm{Al}_{2} \mathrm{O}_{3}$ & 6.69 & 6.27 & 6.88 & 6.12 & 5.76 & 0.41 & 0.34 & 0.11 & 0.21 \\
\hline $\mathrm{Fe}_{2} \mathrm{O}_{3}$ & 10.54 & 9.01 & 9.69 & 8.22 & 14.43 & 18.28 & 19.31 & & \\
\hline $\mathrm{FeO}$ & 8.79 & 10.71 & 10.07 & 10.69 & 7.82 & 4.41 & 4.82 & 7.00 & 6.85 \\
\hline $\mathrm{MnO}$ & 0.18 & 0.20 & 0.25 & 0.21 & 0.09 & 0.54 & 0.44 & 0.30 & 0.25 \\
\hline $\mathrm{MgO}$ & 5.78 & 5.53 & 5.45 & 6.01 & 2.41 & 4.52 & 3.85 & 14.70 & 14.63 \\
\hline $\mathrm{CaO}$ & 6.98 & 6.65 & 7.20 & 7.55 & 3.66 & 9.30 & 8.56 & 23.93 & 24.31 \\
\hline $\mathrm{Na}_{2} \mathrm{O}$ & 7.46 & 7.26 & 7.09 & 6.68 & 10.13 & 8.19 & 8.26 & 0.00 & 0.04 \\
\hline $\mathrm{K}_{2} \mathrm{O}$ & 0.03 & 0.03 & 0.06 & 0.05 & 0.07 & 0.04 & 0.04 & 0.04 & 0.04 \\
\hline \multirow[t]{2}{*}{ Total } & 99.13 & 98.45 & 98.87 & 97.82 & 98.06 & 98.43 & 97.09 & 99.09 & 99.22 \\
\hline & $\mathrm{O}=6$ & & & & & & & & \\
\hline $\mathrm{Si}$ & 1.967 & 1.992 & 1.963 & 1.982 & 2.028 & 2.029 & 2.019 & 1.986 & 1.981 \\
\hline $\mathrm{Ti}$ & 0.008 & 0.007 & 0.007 & 0.011 & 0.012 & 0.003 & 0.003 & 0.003 & 0.002 \\
\hline $\mathrm{Al}$ & 0.296 & 0.280 & 0.307 & 0.275 & 0.258 & 0.019 & 0.016 & 0.005 & 0.009 \\
\hline $\mathrm{Fe}^{3+}$ & 0.298 & 0.257 & 0.276 & 0.236 & 0.413 & 0.530 & 0.571 & & \\
\hline $\mathrm{Fe}^{2+}$ & 0.276 & 0.340 & 0.318 & 0.341 & 0.249 & 0.142 & 0.158 & 0.220 & 0.215 \\
\hline $\mathrm{Mn}$ & 0.006 & 0.006 & 0.008 & 0.007 & 0.003 & 0.018 & 0.015 & 0.010 & 0.008 \\
\hline $\mathrm{Mg}$ & 0.324 & 0.313 & 0.307 & 0.342 & 0.137 & 0.260 & 0.226 & 0.823 & 0.818 \\
\hline $\mathrm{Ca}$ & 0.281 & 0.270 & 0.292 & 0.309 & 0.149 & 0.384 & 0.361 & 0.962 & 0.977 \\
\hline $\mathrm{Na}$ & 0.543 & 0.534 & 0.520 & 0.494 & 0.748 & 0.612 & 0.630 & 0.000 & 0.003 \\
\hline K & 0.001 & 0.001 & 0.003 & 0.002 & 0.003 & 0.002 & 0.002 & 0.002 & 0.002 \\
\hline Sum & 4.000 & 4.000 & 4.001 & 3.999 & 4.000 & 3.999 & 4.001 & 4.011 & 4.015 \\
\hline \multicolumn{10}{|l|}{ Components } \\
\hline Jadeite & 30.93 & 34.15 & 31.73 & 32.16 & 32.09 & 2.09 & 1.71 & & \\
\hline Acmite & 35.05 & 32.31 & 32.45 & 29.51 & 51.33 & 59.43 & 61.95 & & \\
\hline Diopside & 34.02 & 33.54 & 35.82 & 38.33 & 16.58 & 38.48 & 36.34 & & \\
\hline
\end{tabular}

${ }^{\mathrm{a}} \mathrm{Fe}^{3+}$ and $\mathrm{Fe}^{2+}$ of sodic pyroxene were calculated according to formula constraints.

${ }^{b}$ Total $\mathrm{Fe}$ as $\mathrm{FeO}$.

Table 6. Representative analyses of phengite, chlorite, albite, and sphene, Hole 778A.

\begin{tabular}{|c|c|c|c|c|c|c|c|c|}
\hline $\begin{array}{l}\text { Mineral } \\
\text { Sample } 125-778 \mathrm{~A}-\end{array}$ & $\begin{array}{c}\text { Phengite } \\
\text { 9R-CC } \\
\text { Piece } 6\end{array}$ & $\begin{array}{c}\text { Phengite } \\
\text { 9R-CC } \\
\text { Piece } 7\end{array}$ & $\begin{array}{l}\text { Chlorite } \\
\text { 13R-CC } \\
\text { Piece } 4\end{array}$ & $\begin{array}{l}\text { Chlorite } \\
\text { 13R-CC } \\
\text { Piece } 4\end{array}$ & $\begin{array}{c}\text { Albite } \\
6 R-1 \\
\text { Piece } 1\end{array}$ & $\begin{array}{c}\text { Albite } \\
7 \mathrm{R}-1 \\
2-3 \mathrm{~cm}\end{array}$ & $\begin{array}{l}\text { Albite } \\
11 \mathrm{R}-1 \\
5-7 \mathrm{~cm}\end{array}$ & $\begin{array}{c}\text { Sphene } \\
\text { I6R-1 } \\
\text { Piece 1 }\end{array}$ \\
\hline $\mathrm{SiO}_{2}$ & 55.18 & 53.35 & 28.56 & 30.59 & 69.81 & 67.52 & 67.72 & 30.32 \\
\hline $\mathrm{TiO}_{2}$ & 0.04 & 0.05 & 0.08 & 0.04 & 0.06 & 0.05 & 0.08 & 31.91 \\
\hline $\mathrm{Al}_{2} \mathrm{O}_{3}$ & 21.14 & 20.45 & 20.00 & 20.80 & 19.27 & 19.12 & 19.09 & 3.51 \\
\hline $\mathrm{Fe}_{2} \mathrm{O}_{3} * *$ & & & & & 0.28 & 0.49 & 0.37 & \\
\hline $\mathrm{FeO}^{*}$ & 2.66 & 2.87 & 18.46 & 10.65 & & & & 2.14 \\
\hline $\mathrm{MnO}$ & 0.09 & 0.12 & 0.35 & 0.21 & 0.08 & 0.16 & 0.11 & 0.09 \\
\hline $\mathrm{MgO}$ & 4.96 & 4.84 & 21.17 & 26.56 & 0.00 & 0.00 & 0.00 & 0.00 \\
\hline $\mathrm{CaO}$ & 0.05 & 0.12 & 0.10 & 0.08 & 0.09 & 0.15 & 0.20 & 28.09 \\
\hline $\mathrm{Na}_{2} \mathrm{O}$ & 0.00 & 0.00 & 0.00 & 0.00 & 10.64 & 10.69 & 10.71 & 0.00 \\
\hline $\mathrm{K}_{2} \mathrm{O}$ & 10.46 & 10.35 & 0.04 & 0.05 & 0.05 & 0.08 & 0.04 & 0.03 \\
\hline \multirow[t]{2}{*}{ Total } & 94.58 & 92.15 & 88.76 & 88.98 & 100.28 & 98.26 & 98.32 & 96.09 \\
\hline & $\mathrm{O}=22$ & & $\mathrm{O}=28$ & & $\mathrm{O}=8$ & & & $\mathrm{Si}=4$ \\
\hline $\mathrm{Si}$ & 7.393 & 7.364 & 5.711 & 5.834 & 3.025 & 2.998 & 3.002 & 4.000 \\
\hline $\mathrm{Ti}$ & 0.004 & 0.005 & 0.012 & 0.006 & 0.002 & 0.002 & 0.003 & 3.166 \\
\hline $\mathrm{Al}$ & 3.338 & 3.327 & 4.713 & 4.675 & 0.984 & 1.001 & 0.998 & 0.545 \\
\hline $\mathrm{Fe}^{3+}$ & & & & & 0.009 & 0.016 & 0.012 & \\
\hline $\mathrm{Fe}^{2+}$ & 0.298 & 0.331 & 3.087 & 1.699 & & & & 0.236 \\
\hline $\mathrm{Mn}$ & 0.010 & 0.014 & 0.059 & 0.034 & 0.003 & 0.006 & 0.004 & 0.010 \\
\hline $\mathrm{Mg}$ & 0.991 & 0.996 & 6.311 & 7.552 & 0.000 & 0.000 & 0.000 & 0.000 \\
\hline $\mathrm{Ca}$ & 0.007 & 0.018 & 0.021 & 0.016 & 0.004 & 0.007 & 0.010 & 3.970 \\
\hline $\mathrm{Na}$ & 0.000 & 0.000 & 0.000 & 0.000 & 0.894 & 0.920 & 0.921 & 0.000 \\
\hline K & 1.788 & 1.823 & 0.010 & 0.012 & 0.003 & 0.005 & 0.002 & 0.004 \\
\hline Sum & 13.829 & 13.878 & 19.924 & 19.828 & 4.924 & 4.955 & 4.952 & 11.931 \\
\hline
\end{tabular}

Note: ${ }^{*}$ Total $\mathrm{Fe}$ as $\mathrm{FeO}$. ${ }^{* *} \mathrm{Total} \mathrm{Fe}$ as $\mathrm{Fe}_{2} \mathrm{O}_{3}$. 

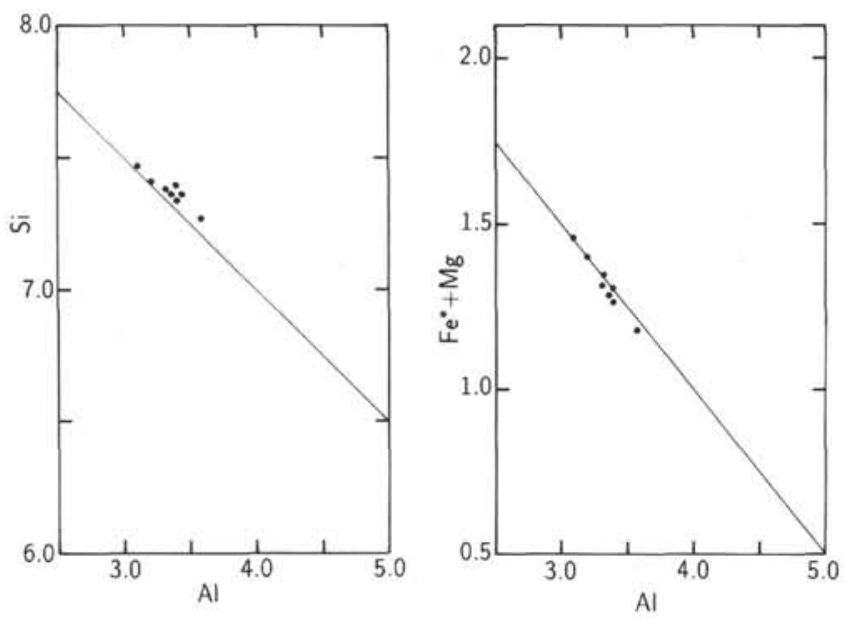

Figure 10. Chemical compositions of phengite on $\mathrm{Si}-\mathrm{Al}$ and $\left(\mathrm{Fe}^{*}+\mathrm{Mg}\right)-\mathrm{Al}$ diagrams. The solid lines correspond to the ideal muscovite-Al-celadonite junction.

In Hole $778 \mathrm{~A}$, the characteristic mineral association is lawsonite and pumpellyite. The $\mathrm{Fe}^{3+}$ contents in lawsonite show a positive correlation with those of associated pumpellyite, and lawsonite and pumpellyite in hematite-bearing samples contain higher $\mathrm{Fe}^{3+}$ contents than those in hematite-free samples. Sodic pyroxene does not coexist with lawsonite, but coexists stably with pumpellyite. The Hole 778 A rocks are characterized by the low variance (three-phase) assemblage, lawsonite + pumpellyite + hematite, and the presence of this assemblage does not permit the possible stable association of lawsonite and blue amphibole, which is common in the higher-grade blueschists in the Franciscan terrane (Maruyama et al., 1986).

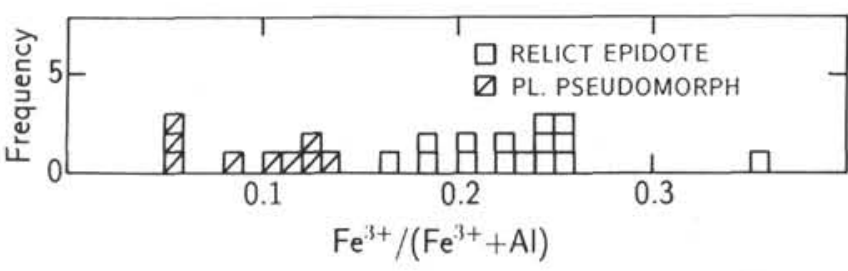

Figure 11. Frequency distribution of $\mathrm{Fe}^{3+} /\left(\mathrm{Fe}^{3+}+\mathrm{Al}\right)$ ratio for epidote.

The approximate metamorphic conditions can be estimated from theoretical and experimental investigations (Fig. 14). The presence of aragonite, instead of calcite, provides evidence that the pressure was above the aragonite-calcite inversion curve $\left(>4.5 \mathrm{~kb}\right.$ at $150^{\circ} \mathrm{C}$ and $>6 \mathrm{~kb}$ at $200^{\circ} \mathrm{C}$ ) (Carlson, 1983). The jadeite component of the sodic pyroxene, which is accompanied with quartz and albite, is about 30 $\mathrm{mol} \%$. Using the calibrated isopleths in the jadeite component after Brown and Ghent (1983), we estimate pressures of $5 \mathrm{~kb}$ at $150^{\circ} \mathrm{C}$ and $6 \mathrm{~kb}$ at $250^{\circ} \mathrm{C}$. The reaction of heulandite $=$ lawsonite + quartz $+\mathrm{H}_{2} \mathrm{O}$ gives a minimum temperature stability limit of $200^{\circ} \mathrm{C}$ for the lawsonite + quartz association (Nitsch, 1968) and the reaction of lawsonite + pumpellyite $=$ zoisite + chlorite + quartz $+\mathrm{H}_{2} \mathrm{O}$ gives a maximum temperature limit of $250^{\circ} \mathrm{C}$ for the lawsonite + pumpellyite association (Liou et al., 1985). The $\mathrm{Fe}_{2} \mathrm{O}_{3}$ content in lawsonite probably affects these stability limits. Liou et al. (1985) demonstrated that the introduction of $\mathrm{Fe}_{2} \mathrm{O}_{3}$ in the latter reaction shifts the reaction curve to the low temperature side. Thus, the metamorphic conditions can be roughly estimated at $150^{\circ}$ to $250^{\circ} \mathrm{C}$ and 4.5 to $6 \mathrm{~kb}$ (Fig. 14).

The metamorphic rocks from Hole 779A characteristically contain garnet, pumpellyite, and zeolite as metamorphic minerals. Because the rocks from Hole 779A do not contain quartz and albite, we cannot evaluate the mineral paragenesis of these rocks. However, tentative plots of garnet and pumpellyite on the $2 \mathrm{Fe}^{3+}-\mathrm{Ca}-\mathrm{AFM}$ diagram

Table 7. Representative analyses of garnet, thomsonite, natrolite, chlorite, and sphene, Hole 779A.

\begin{tabular}{|c|c|c|c|c|c|c|c|}
\hline $\begin{array}{l}\text { Mineral } \\
\text { Sample } 125-779 \mathrm{~A} \text { - }\end{array}$ & $\begin{array}{c}\text { Garnet } \\
31 \text { R-CC } \\
\text { Piece } 7\end{array}$ & $\begin{array}{c}\text { Garnet } \\
31 \mathrm{R}-\mathrm{CC} \\
\text { Piece } 7\end{array}$ & $\begin{array}{c}\text { Thomsonite } \\
\text { 9R-1 } \\
\text { Piece 7B }\end{array}$ & $\begin{array}{l}\text { Natrolite } \\
\text { 9R-1 } \\
\text { Piece 7B }\end{array}$ & $\begin{array}{c}\text { Natrolite } \\
\text { 9R-1 } \\
\text { Piece 7C }\end{array}$ & $\begin{array}{l}\text { Chlorite } \\
31 \mathrm{R}-\mathrm{CC} \\
\text { Piece } 7\end{array}$ & $\begin{array}{c}\text { Sphene } \\
\text { 9R-1 } \\
\text { Piece 7C }\end{array}$ \\
\hline $\mathrm{SiO}_{2}$ & 32.35 & 30.20 & 39.06 & 45.99 & 45.05 & 28.43 & 30.81 \\
\hline $\mathrm{TiO}_{2}$ & 5.16 & 6.21 & 0.05 & 0.06 & 0.06 & 0.09 & 29.92 \\
\hline $\mathrm{Al}_{2} \mathrm{O}_{3}$ & 12.48 & 12.69 & 30.51 & 27.14 & 26.66 & 17.26 & 5.08 \\
\hline $\mathrm{Fe}_{2} \mathrm{O}_{3}^{* *}$ & 9.44 & 8.14 & 0.21 & 0.09 & 0.14 & & \\
\hline $\mathrm{FeO}^{*}$ & & & & & & 23.14 & 2.22 \\
\hline $\mathrm{MnO}$ & 0.10 & 0.09 & 0.09 & 0.09 & 0.12 & 0.09 & 0.07 \\
\hline $\mathrm{MgO}$ & 0.00 & 0.00 & 0.00 & 0.00 & 0.00 & 17.26 & 0.00 \\
\hline $\mathrm{CaO}$ & 36.22 & 36.33 & 11.38 & 0.54 & 0.64 & 0.07 & 28.06 \\
\hline $\mathrm{Na}_{2} \mathrm{O}$ & 0.00 & 0.00 & 3.76 & 14.05 & 12.88 & 0.00 & 0.00 \\
\hline $\mathrm{K}_{2} \mathrm{O}$ & 0.12 & 0.11 & 0.07 & 0.06 & 0.07 & 0.02 & 0.11 \\
\hline Total & 95.87 & 93.77 & 85.13 & 88.02 & 85.62 & 86.36 & 96.27 \\
\hline & $\mathrm{O}=12$ & & $\mathrm{O}=20$ & & & $\mathrm{O}=28$ & $\mathrm{Si}=4$ \\
\hline $\mathrm{Si}$ & 2.693 & 2.581 & 5.267 & 5.955 & 5.975 & 5.996 & 4.000 \\
\hline $\mathrm{Ti}$ & 0.323 & 0.399 & 0.005 & 0.006 & 0.006 & 0.014 & 2.921 \\
\hline $\mathrm{Al}$ & 1.224 & 1.278 & 4.848 & 4.142 & 4.167 & 4.290 & 0.778 \\
\hline $\mathrm{Fe}^{3+}$ & 0.591 & 0.523 & 0.021 & 0.009 & 0.014 & & \\
\hline $\mathrm{Fe}^{2+}$ & & & & & & 4.082 & 00.241 \\
\hline Mn & 0.007 & 0.007 & 0.010 & 0.010 & 0.013 & 0.016 & 0.008 \\
\hline $\mathrm{Mg}$ & 0.000 & 0.000 & 0.000 & 0.000 & 0.000 & 5.427 & 0.000 \\
\hline $\mathrm{Ca}$ & 3.231 & 3.326 & 1.644 & 0.075 & 0.091 & 0.016 & 3.904 \\
\hline $\mathrm{Na}$ & 0.000 & 0.000 & 0.983 & 3.527 & 3.312 & 0.000 & 0.000 \\
\hline $\mathrm{K}$ & 0.013 & 0.013 & 0.012 & 0.010 & 0.012 & 0.005 & 0.017 \\
\hline Sum & 8.082 & 8.127 & 12.790 & 13.734 & 13.590 & 19.846 & 11.869 \\
\hline
\end{tabular}

Note: ${ }^{*}$ Total $\mathrm{Fe}$ as $\mathrm{FeO}$. **Total $\mathrm{Fe}$ as $\mathrm{Fe}_{2} \mathrm{O}_{3}$. 


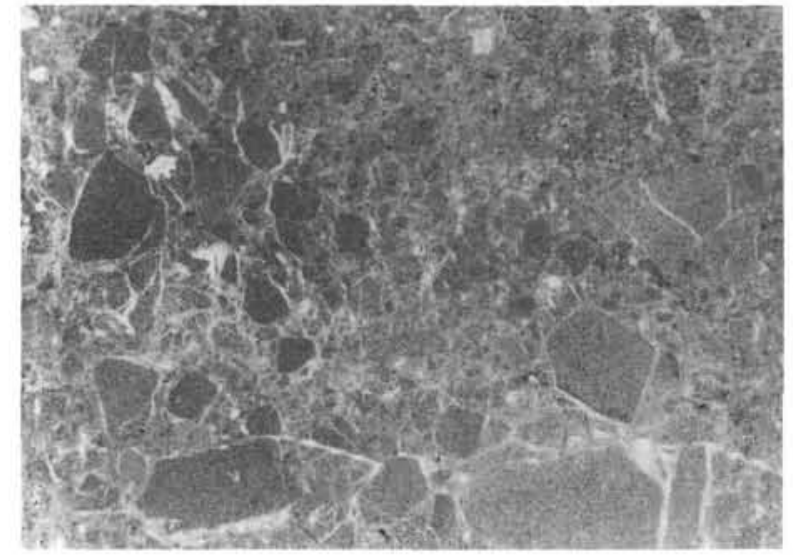

A

$2.05 \mathrm{~cm}$

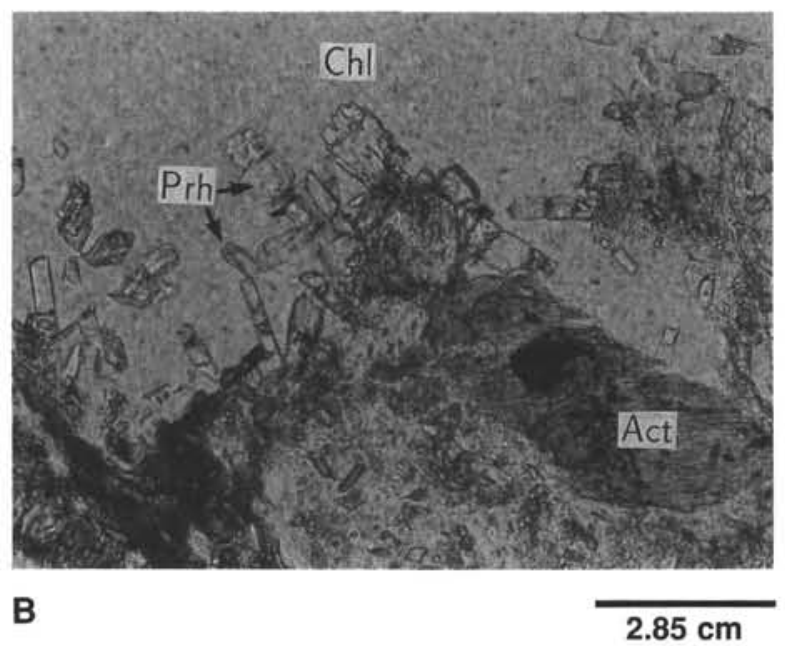

Figure 12. Thin-section photomicrographs (both in plane polarized light). A. Late-stage fracturing of the metabasalt. Sample 125-784A-40R-1, $13-15 \mathrm{~cm}$. B. Modes of occurrence of prehnite and actinolite. Sample 125784A-40R-1, 10-12 cm. Prh = prehnite, $\mathrm{Act}=$ actinolite, $\mathrm{Chl}=$ chlorite .

suggest that the pumpellyite + garnet association in rocks from Hole 779 A contrasts with the lawsonite + pumpellyite + hematite assemblage in rocks from Hole $778 \mathrm{~A}$ in a fixed P-T condition. Garnet associated with pumpellyite has been reported from the zeolite facies rocks at Takitimu, New Zealand (Houghton, 1982). The metamorphism of the rocks from Hole 779A probably differs from that of rocks from Hole 778A, and may belong to the zeolite facies.

\section{Holes $783 \mathrm{~A}$ and $784 \mathrm{~A}$}

The mineral assemblages observed in rocks from Holes 783A and $784 \mathrm{~A}$ are graphically represented in Figure 13 . The low variance assemblage of these rocks is actinolite + epidote + prehn-ite, with the constant subassemblage of chlorite + quartz + albite $+\mathrm{H}_{2} \mathrm{O}$, which is a diagnostic assemblage of the prehnite-actinolite facies as proposed recently by Liou et al. $(1985,1987)$. This mineral assemblage has been reported from low-pressure metamorphic terranes (Sekiet al., 1969; Arai, 1987; Kuniyoshi and Liou, 1976; Everts and Schiffman, 1983; Ishizuka, 1985; Cho et al., 1987), and recently from ocean-floor metabasalts (Ishizuka, 1989). According to the P-T diagram of Liou et al. (1985; 1987), the metamorphic conditions of the rocks from Holes $783 \mathrm{~A}$ and $784 \mathrm{~A}$ may be roughly estimated at $200^{\circ}$ to $300^{\circ} \mathrm{C}$ and 1 to $2 \mathrm{~kb}$.

\section{Significance of Blueschist Facies Clasts from the Serpentinite Seamount in the Mariana Forearc}

Since the Eocene (about $45 \mathrm{Ma}$ ), the Pacific Plate has been subducting along the Mariana Trench at about $10 \mathrm{~cm} / \mathrm{yr}$ beneath the Philippine Sea Plate (Uyeda and Ben-Avraham, 1972). The mantle peridotite above the subducting slab has reacted with water to form serpentinite, and the resulting low-density serpentinite has risen to form a zone of seamounts between 50 and $150 \mathrm{~km}$ from the trench (Fryer et al., 1985). Conical Seamount, situated at about $30 \mathrm{~km}$ above the subducting slab, is considered to be one of these typical diapiric seamounts, and the fluids, which converted peridotite to serpentinite and probably played an important role in giving rise to diapirism, are still actively upwelling, probably from the subducting slab to the summit of the seamount (Mottl et al., 1989). The blueschist facies clasts recovered from Hole $778 \mathrm{~A}$ are reasonably considered to have been formed at about 13 to $18 \mathrm{~km}$ below the seamount sometime after the initiation of subduction; thus, this diapirism may have initiated from at least that depth. Pre- or syn-metamorphic cataclastic deformation is ubiquitous in these clasts. Such brittle deformation is consistent with low-temperature metamorphism within subduction zones. A detrital fragment of lawsonite has been reported from DSDP Site 453, on the western edge of the Mariana Trough (Shipboard Scientific Party, 1981). The uplift of blueschist facies rocks by serpentinite diapirism in the Mariana forearc may have started before the initiation of back-arc opening at 5 to $6 \mathrm{Ma}$ (Karig, 1971).

During the last two decades, most blueschist facies metamorphic rocks have been surmised to occur in and around subduction zones (Takeuchi and Uyeda, 1965; Dewey and Bird, 1970; Ernst, 1971; Coleman, 1972; Fryer and Fryer, 1987). Making the reasonable assumption that the metamorphism is younger than $45 \mathrm{Ma}$, this discovery presents direct evidence that a blueschist facies metamorphism actually takes place within a subduction zone.

Numerous tectonic models that explain the uplift process of high $\mathrm{P} / \mathrm{T}$ blocks have been proposed, mainly for the Franciscan terrane (Coleman, 1961; Ernst, 1965; Lockwood, 1971; Suppe, 1972; Cowan and Page, 1975; Cloos, 1982; Carlson, 1984). The modes of occurrence of blueschist facies clasts in serpentinite seamounts in the modern Mariana forearc system fit the models that attribute the uplift of blueschists to serpentinite diapirism in forearc regions (Coleman, 1961; Ernst, 1965; Lockwood, 1971; Carlson, 1984). We conclude that serpentinite diapirism could have been one of the main mechanisms to uplift blueschist tectonic blocks from the subduction zone to the forearc surface, at least in some blueschist facies terranes. This mechanism may have caused recycling of the blueschists recognized in the Franciscan and in the Kamuikotan blueschist facies terranes, Japan (Platt et al., 1976; Moore and Liou, 1980; Ishizuka et al., 1983; Watanabe and Maekawa, 1985).

\section{Origin of Metamorphic Rocks from Holes 783A and 784A}

The prehnite-actinolite facies metamorphism recognized in the rocks from Holes $783 \mathrm{~A}$ and $784 \mathrm{~A}$ is a low-pressure type that is comparable to the ocean-floor type of metamorphism that was recognized in Hole 504B near the Costa Rica Rift (Ishizuka, 1989). Regarding the origin of these metamorphic rocks, there may be two possibilities: (1) these metamorphic rocks were derived from trapped oceanic crust in the Mariana forearc, which was metamorphosed under low-pressure conditions, or (2) these metamorphic rocks represent in-situ metamorphism that occurred at depths beneath the island arc. Our knowledge about metamorphism beneath the ocean floor and island arcs is insufficient for us to come to firm conclusions about the origin of the rocks at Holes 783A and 784A. Geochemical studies may provide the necessary constraints in addressing the precise origin of these rocks.

We lack the essential data necessary to make a full evaluation of the metamorphic conditions and origin of the older metamorphism, 
Table 8. Mineral associations of metamorphosed mafic rocks in Holes 783A and 784A.

\begin{tabular}{|c|c|c|c|c|c|c|c|c|c|c|c|c|c|}
\hline \multirow{2}{*}{$\begin{array}{l}\text { Core, section, } \\
\text { interval }(\mathrm{cm})\end{array}$} & \multirow{2}{*}{$\begin{array}{l}\text { Depth } \\
\text { (mbsf) }\end{array}$} & \multicolumn{10}{|c|}{ Low-grade metamorphic minerals } & \multicolumn{2}{|c|}{ Relict minerals } \\
\hline & & Ep & Prh & Act & $\mathrm{Chl}$ & Qtz & $\mathrm{Ab}$ & $\mathrm{Cal}$ & Zeo & Spn & Opq & Cpx & $\mathrm{Hbl}$ \\
\hline \multicolumn{14}{|l|}{$125-783 \mathrm{~A}-$} \\
\hline $15 R-2,85-87$ & 132.0 & & & & $\mathrm{x}$ & & & & & $\mathrm{x}$ & & $\mathrm{x}$ & \\
\hline${ }^{\mathrm{a}} 15 \mathrm{R}-2,107-109$ & 132.2 & $\mathrm{x}$ & $\mathrm{x}$ & $\mathrm{x}$ & $\mathrm{x}$ & $\mathrm{x}$ & $\mathrm{x}$ & & & $\mathrm{x}$ & & $\mathrm{x}$ & $\mathrm{x}$ \\
\hline "15R-CC, 4-6 & 139.1 & $\mathrm{x}$ & & $\mathrm{x}$ & $\mathrm{x}$ & $\mathrm{x}$ & $\mathrm{x}$ & & & $\mathrm{x}$ & & $\mathrm{x}$ & \\
\hline${ }^{\mathrm{a}} 18 \mathrm{R}-1,0-3$ & 158.6 & $\mathrm{x}$ & & & $\mathrm{x}$ & & & & $\mathrm{x}$ & & & $\mathrm{x}$ & \\
\hline \multicolumn{14}{|l|}{$125-784 \mathrm{~A}-$} \\
\hline $35 \mathrm{R}-\mathrm{CC}, 7-8$ & 329.0 & & & $\mathrm{x}$ & $\mathrm{x}$ & & & & & & $\mathrm{x}$ & & \\
\hline $38 \mathrm{R}-1,29-30$ & 348.6 & & & $x$ & $\mathrm{x}$ & & & & & & & & \\
\hline a $39 \mathrm{R}-1,5-6$ & 358.0 & & & $\mathrm{x}$ & $\mathrm{x}$ & & $\mathrm{x}$ & & & $\mathrm{x}$ & $\mathrm{x}$ & $\mathrm{x}$ & $\mathrm{x}$ \\
\hline "40R-1, 10-12 & 367.6 & & $\mathrm{x}$ & $x$ & $\mathrm{x}$ & $x$ & $\mathrm{x}$ & $x$ & & & & $\mathrm{x}$ & \\
\hline $40 \mathrm{R}-1,12-15$ & 367.6 & $x$ & & $x$ & $\mathrm{x}$ & & & $x$ & & $x$ & & & \\
\hline $40 \mathrm{R}-1,13-15$ & 367.6 & & & & $x$ & & & $\mathrm{x}$ & & $x$ & & $\mathrm{x}$ & \\
\hline${ }^{a} 41 R-1,8-9$ & 377.4 & & & & $\mathrm{x}$ & & & & & $x$ & & & \\
\hline $41 R-1,9-10$ & 377.4 & & & & $\mathrm{x}$ & & & & & & & $\mathrm{x}$ & \\
\hline
\end{tabular}

Notes: Prh $=$ prehnite. Other abbreviations are the same as in Table 1. All more or less include clay minerals.

analyzed samples.

Table 9. Representative analyses of prehnite, epidote, actinolite, and chlorite, Hole 783A.

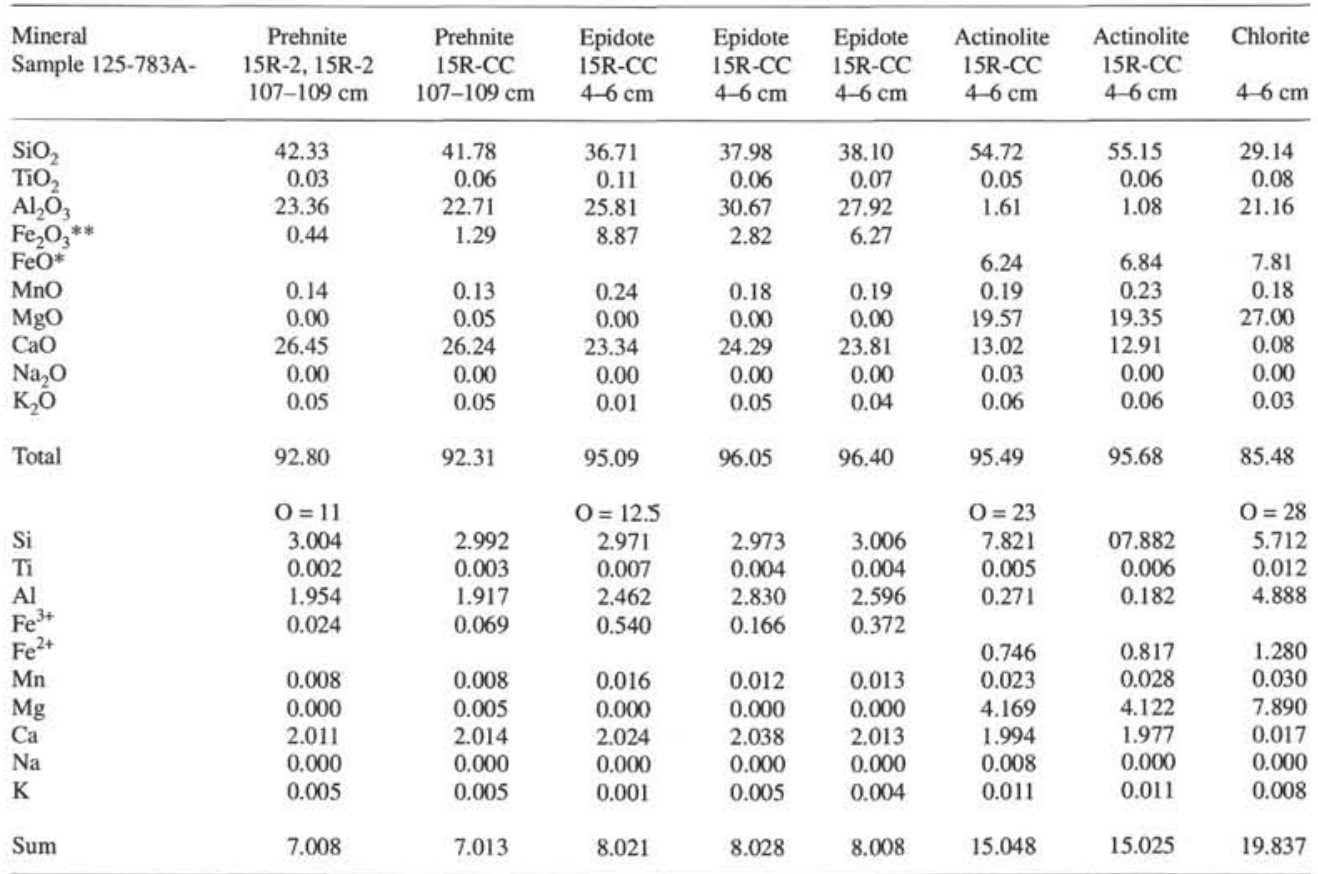

Note: *Total $\mathrm{Fe}$ as FeO. ** Total $\mathrm{Fe}$ as $\mathrm{Fe}_{2} \mathrm{O}_{3}$.

namely that characterized by the occurrence of relict hornblendeand/or epidote-bearing clasts from Holes 778A, 783A, and 784A. No foliation or lineation was recognized in these rocks, and original igneous textures are commonly well preserved. Qualitative EDS analyses of hornblende indicate that some hornblendes contain detectable amounts of $\mathrm{Cl}$, which may suggest that the metamorphism may have involved saline hydrothermal fluids. This may in turn suggest that these rocks underwent low-pressure ocean-floor metamorphism. Further study will be necessary to reveal the nature and origin of this metamorphism.

\section{ACKNOWLEDGMENTS}

This study was conducted while H. M. was at the Western Washington University. He thanks Dr. E. H. Brown for valuable discussion and for providing facilities in the laboratory. Thoughtful and critical reviews by Drs. J. G. Liou, K. M. Gillis, and J. A. Pearce are gratefully acknowledged. We thank Mrs. D. R. Ross for the XRD analyses. This research was supported by a grant from the Yamada Science Foundation (to H. M.) and by a Grant-in-Aid from the Ministry of Education of Japan (6242001/N. Fujii). 
Table 10. Representative analyses of prehnite, epidote, actinolite, and chlorite, Hole 784A.

\begin{tabular}{|c|c|c|c|c|c|c|}
\hline $\begin{array}{l}\text { Mineral } \\
\text { Sample 125-784A- }\end{array}$ & $\begin{array}{c}\text { Prehnite } \\
40 \mathrm{R}-1 \\
10-12 \mathrm{~cm}\end{array}$ & $\begin{array}{c}\text { Prehnite } \\
40 \mathrm{R}-1 \\
10-12 \mathrm{~cm}\end{array}$ & $\begin{array}{c}\text { Epidote } \\
40 \mathrm{R}-1 \\
12-15 \mathrm{~cm}\end{array}$ & $\begin{array}{c}\text { Epidote } \\
40 \mathrm{R}-1 \\
12-15 \mathrm{~cm}\end{array}$ & $\begin{array}{c}\text { Actinolite } \\
40 \mathrm{R}-1 \\
10-12 \mathrm{~cm}\end{array}$ & $\begin{array}{c}\text { Chlorite } \\
40 \mathrm{R}-1 \\
10-12 \mathrm{~cm}\end{array}$ \\
\hline $\mathrm{SiO}_{2}$ & 42.66 & 42.66 & 36.47 & 36.49 & 54.28 & 30.59 \\
\hline $\mathrm{TiO}_{2}$ & 0.05 & 0.05 & 0.06 & 0.06 & 0.10 & 0.10 \\
\hline $\mathrm{Al}_{2} \mathrm{O}_{3}$ & 24.09 & 24.27 & 22.97 & 23.64 & 1.52 & 17.04 \\
\hline $\mathrm{Fe}_{2} \mathrm{O}_{3}$ ** & 0.42 & 0.51 & 12.36 & 10.95 & & \\
\hline $\mathrm{FeO}^{*}$ & & & & & 7.53 & 11.39 \\
\hline $\mathrm{MnO}$ & 0.19 & 0.11 & 0.30 & 0.17 & 0.17 & 0.19 \\
\hline $\mathrm{MgO}$ & 0.00 & 0.05 & 0.00 & 0.00 & 18.90 & 26.89 \\
\hline $\mathrm{CaO}$ & 27.15 & 27.43 & 22.77 & 22.97 & 12.71 & 0.06 \\
\hline $\mathrm{Na}_{2} \mathrm{O}$ & 0.00 & 0.00 & 0.00 & 0.00 & 0.03 & 0.00 \\
\hline $\mathrm{K}_{2} \mathrm{O}$ & 0.07 & 0.06 & 0.03 & 0.04 & 0.04 & 0.03 \\
\hline \multirow[t]{2}{*}{ Total } & 94.63 & 95.14 & 94.96 & 94.32 & 95.28 & 86.29 \\
\hline & $\mathrm{O}=11$ & & $\mathrm{O}=12.5$ & & $\mathrm{O}=23$ & $\mathrm{O}=28$ \\
\hline $\mathrm{Si}$ & 2.975 & 2.963 & 2.994 & 3.001 & 7.820 & 6.061 \\
\hline Ti & 0.003 & 0.003 & 0.004 & 0.004 & 0.011 & 0.015 \\
\hline $\mathrm{Al}$ & 1.980 & 1.986 & 2.223 & 2.291 & 0.258 & 3.979 \\
\hline $\mathrm{F}^{3+}$ & 0.022 & 0.027 & 0.763 & 0.677 & & \\
\hline $\mathrm{Fe}^{2+}$ & & & & & 0.907 & 1.887 \\
\hline $\mathrm{Mn}$ & 0.001 & 0.006 & 0.021 & 0.012 & 0.021 & 0.032 \\
\hline $\mathrm{Mg}$ & 0.000 & 0.005 & 0.000 & 0.000 & 4.059 & 7.943 \\
\hline $\mathrm{Ca}$ & 2.028 & 2.041 & 2.003 & 2.024 & 1.962 & 0.013 \\
\hline $\mathrm{Na}$ & 0.000 & 0.000 & 0.000 & 0.000 & 0.000 & 0.000 \\
\hline K & 0.006 & 0.005 & 0.003 & 0.004 & 0.008 & 0.008 \\
\hline Sum & 7.025 & 7.036 & 8.011 & 8.013 & 15.046 & 19.938 \\
\hline
\end{tabular}

Note: *Total $\mathrm{Fe}$ as $\mathrm{FeO},{ }^{* *}$ Total $\mathrm{Fe}$ as $\mathrm{Fe}_{2} \mathrm{O}_{3}$.
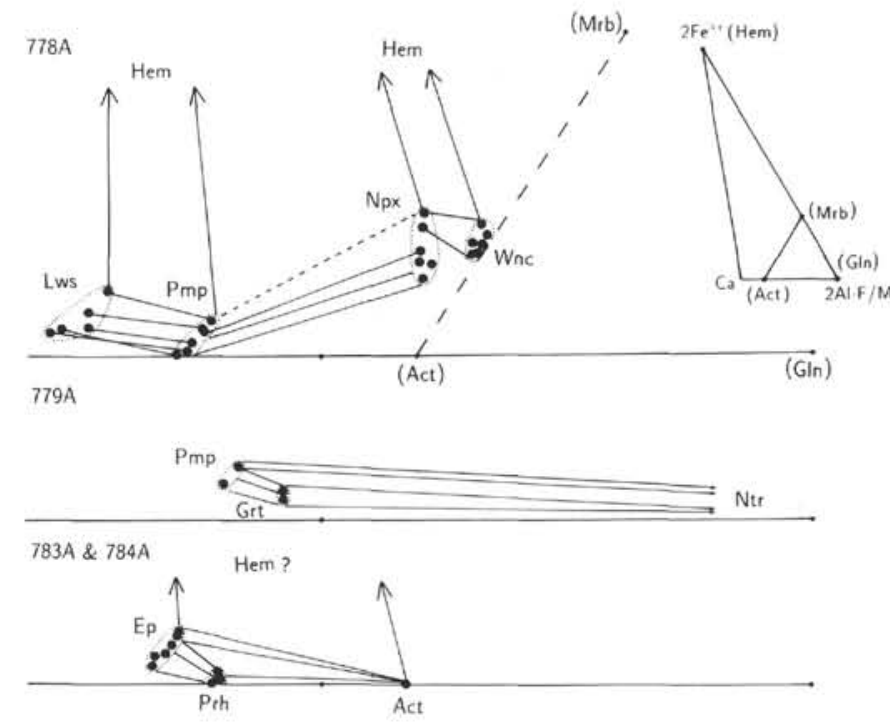

Figure 13. Paragenetic phase relations of the low-grade metamorphic rocks from Hole $778 \mathrm{~A}$ and Holes $783 \mathrm{~A}$ and $784 \mathrm{~A}$ graphically represented in the $2 \mathrm{Fe}^{3+}-\mathrm{Ca}-\mathrm{AFM}(2 \mathrm{Al} \cdot \mathrm{F} / \mathrm{M})$ ternary system projected from quartz, albite, chlorite, $\mathrm{H}_{2} \mathrm{O}$, and $\mathrm{CO}_{2}$. Act $=$ actinolite, $\mathrm{Mrb}=$ magnesioriebeckite, $\mathrm{Gln}=$ glaucophane, $\mathrm{Wnc}=$ winchite, $\mathrm{Hem}=$ hematite, $\mathrm{Lws}=$ lawsonite, $\mathrm{Pmp}=$ pumpellyite, $\mathrm{Grt}=$ garnet, $\mathrm{Ntr}=$ natrolite, $\mathrm{Ep}=$ epidote, $\mathrm{Prh}=$ prehnite. 
$\mathrm{Kb}$

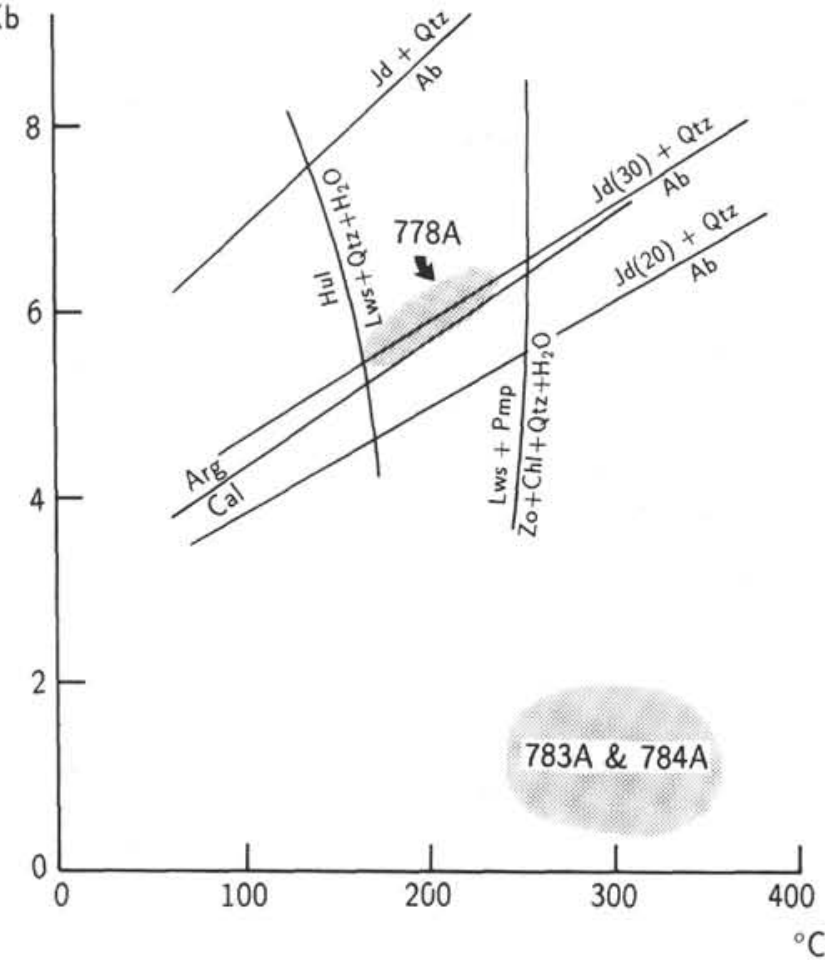

Figure 14. Approximate metamorphic conditions of the rocks from Hole 778A Pressure-temperature curves for some pertinent metamorphic relations are also shown in this figure. Data from Newton and Smith (1967); Nitsch (1968); Liou et al. (1985); Carlson (1983). $\mathrm{Arg}=$ aragonite, $\mathrm{Cal}=$ calcite, $\mathrm{Hul}=$ heulandite, Lws $=$ lawsonite, $\mathrm{Qtz}=$ quartz, $\mathrm{Jd}=$ jadeite, $\mathrm{Ab}=$ albite, $\mathrm{Pmp}=$ pumpellyite, $\mathrm{Zo}=$ zoisite, $\mathrm{Chl}=$ chlorite .

Table 11. Projection matrix used to construct the diagram in Figure 13.

\begin{tabular}{lcccccccc}
\hline & $\mathrm{Si}$ & $\mathrm{Al}$ & $\mathrm{Fe}^{3+}$ & $\mathrm{FM}^{\mathrm{a}}$ & $\mathrm{Ca}$ & $\mathrm{Na}$ & $\mathrm{H}$ & $\mathrm{C}$ \\
\hline Quartz & 1 & 0 & 0 & 0 & 0 & 0 & 0 & 0 \\
Albite & 3 & 1 & 0 & 0 & 0 & 1 & 0 & 0 \\
Chlorite & 2.86 & 2.38 & 0 & 4.66 & 0 & 0 & 8 & 0 \\
$\mathrm{H}_{2} \mathrm{O}$ & 0 & 0 & 0 & 0 & 0 & 0 & 2 & 0 \\
$\mathrm{CO}_{2}$ & 0 & 0 & 0 & 0 & 0 & 0 & 0 & 1 \\
$\mathrm{Al}$ & 0 & -3.88 & 0 & 2.94 & 0 & 0 & 0 & 0 \\
$\mathrm{Ca}^{3+}$ & 0 & 0 & 0 & 0 & 1 & 0 & 0 & 0 \\
$\mathrm{Fe}^{3+}$ & 0 & 0 & 8.45 & 0 & 0 & 0 & 0 & 0 \\
& & & & & & & &
\end{tabular}

${ }^{\mathrm{a}} \mathrm{FM}=\mathrm{Fe}^{2+}+\mathrm{Mg}$.

\section{REFERENCES}

Arai, T., 1987. Tectonics of Tanzawa Mountains - constraints from metamorphic petrology. J. Geol. Soc. Japan, 93:185-200.

Banno, S., 1959. Aegirineaugites from crystalline schists in Shikoku. J. Geol. Soc. Japan, 65:652-657.

Bloomer, S. H., 1983. Distribution and origin of igneous rocks from the landward slopes of the Mariana Trench: implications for its structure and evolution. J. Geophys. Res., 88:7411-7428.

Bloomer, S. H., and Hawkins, J. W., 1983. Gabbroic and ultramafic rocks from the Mariana trench: an island arc ophiolite. In Hayes, D. E. (Ed.), The Tectonic and Geologic Evolution of Southeast Asian Seas and Islands (Pt. 2). Am. Geophys. Union, AGU Monogr. Ser., 23:294-317.

Brown, E. H., and Ghent, E. D., 1983. Mineralogy and phase relations in the blueschist facies of the Black Butte and Ball Rock areas, northern California Coast Ranges. Am. Mineral., 68:365-372.
Carlson, C., 1984. Stratigraphic and structural significance of foliate serpentinite breccias, Wilbur Springs. Soc. Econ. Paleontol. Mineral., Field Trip Guidebook, 3:108-112.

Carlson, W. D., 1983. The polymorphs of $\mathrm{CaCO}_{3}$ and the aragonite-calcite transformation. Mineral. Soc. Am. Rev. Mineral., 11:191-225.

Cho, M., Liou, J. G., and Maruyama, S., 1987. Transition from metabasites, the zeolite to prehnite-pumpellyite facies in the Karmutsen metabasites, Vancouver Island, B.C. J. Petrol., 28:417-443.

Cloos, M., 1982. Flow melanges: numerical modeling and geologic constraints on their origin in the Franciscan subduction complex, California. Geol. Soc. Am. Bull., 93:330-345.

Coleman, R. G., 1961. Jadeite deposits of the Clear Creek area, New Idria district, San Benito County California. J. Petrol., 2:207-247.

, 1972. Blueschist metamorphism and plate tectonics. Proc. 24th Int. Geol. Congr., Sect. 2, 19-26.

Cowan, D. S., and Page, B. M., 1975. Recycled Franciscan material in Franciscan melange west of Paso Robles, California. Geol. Soc. Am. Bull. $86: 1089-1095$.

Dewey, J. F., and Bird, J. M., 1970. Mountain belt and the new global tectonics. J. Geophys. Res., 75:2625-2647.

Dietrich, V., Emmerman, R., Oberhansli, R., and Puchelt, H., 1978. Geochemistry of basaltic and gabbroic rocks from the West Mariana Basin and the Mariana Trench. Earth Planet. Sci. Lett., 39:127-144.

Ernst, W. G., 1965. Mineral paragenesis in Franciscan metamorphic rocks, Panoche Pass, California. Geol. Soc. Am. Bull., 76:879-914.

1971. Metamorphic zonations on presumably subducted lithospheric plates from Japan, California and the Alps. Contrib. Mineral. Petrol., 34:43-59.

Evans, C., and Hawkins, J., 1979. Mariana arc-trench system: petrology of "seamounts" on the trench-slope break. Eos, 60:968.

Everts, R. C., and Schiffman, P., 1983. Submarine hydrothermal metamorphism of the Del Puerto ophiolite, California. Am. J. Sci., 283:289-340.

Fryer, P., Ambos, E. L., and Hussong, D. M., 1985. Origin and emplacement of Mariana forearc seamounts. Geology, 13:774-777.

Fryer, P., and Fryer, G. J., 1987. Origins of non-volcanic seamounts in a forearc environment. In Keating, B., Fryer, P., Batiza, R., and Boehlert, G. W. (Eds.), Seamounts, Islands, and Atolls. Am. Geophys. Union, AGU Monogr. Ser., 43:61-69.

Gouchi, N., and Banno, S., 1974. Find of aragonite from Kamuikotan metamorphic rocks. Proc. Jpn. Acad., 50:481-486.

Greenwood, H. J., 1975. Thermodynamically valid projections of extensive phase relationships. Am. Mineral., 60:1-8.

Haggerty, J. A., 1987. Petrology and geochemistry of Neogene sedimentary rocks from Mariana forearc seamounts: implications for emplacement of the seamounts. In Keating, B., Fryer, P., Batiza, R., and Boehlert, G. W. (Eds.), Seamounts, Islands, and Atolls. Am. Geophys. Union., AGU Monogr. Ser., 43:175-185.

Hawkins, J., Bloomer, S., Evans, C., and Melchior, J., 1979. Mariana arctrench system: petrology of the inner trench wall. Eos, 60:968.

Honza, E., and Kagami, H., 1977. A possible accretion accompanied by ophiolite in the Mariana trench. J. Geogr., Tokyo Geogr. Soc., 86:80-91.

Houghton, B. F., 1982. Low-grade metamorphism of the Takitimu Group, western Southland, New Zealand. N. Z. J. Geol. Geophys., 25:1-19.

IGCP Working Group, 1977. "Ophiolites": initial report of the geological study of oceanic crust of the Philippine Sea floor. Ofioliti, 2:137-168.

Ishii, T., 1985. Dredged samples from the Ogasawara fore-arc seamount or "Ogasawara paleoland"-"fore-arc ophiolite." In Nasu, N., Kobayashi, K., Kushiro, I., Kagami, H. (Eds.), Formation of Active Ocean Margins: Tokyo (Terra Sci. Publ.), 307-342.

Ishizuka, H., 1985. Prograde metamorphism of the Horokanai ophiolite in the Kamuikotan zone, Hokkaido, Japan. J. Petrol., 26:391-417.

1989. Mineral paragenesis of altered basalts from Hole 504B, ODP Leg 111. In Becker, K., Sakai, H., et al., Proc. ODP, Sci. Results, 111: College Station, TX (Ocean Drilling Program), 61-76.

Ishizuka, H., Imaizumi, M., Gouchi, N., and Banno, S., 1983. The Kamuikotan zone in Hokkaido, Japan: tectonic mixing of high-pressure and low-pressure metamorphic rocks. J. Metamorph. Geol., 1:263-275.

Jarosewich, E., Nelen, J. A., and Norberg, J. A., 1980. Reference samples for electron microprobe analysis. Geostand. Newsl., 4:43-47.

Johnson, L. E., and Fryer, P., 1990. The first evidence of MORB-like lavas from the outer Mariana forearc: geochemistry, petrography and tectonic implications. Earth Planet. Sci. Lett., 100:304-316. 
Karig, D. E., 1971. Structural history of the Mariana Island Arc system. Geol. Soc. Am. Bull., 82:323-344.

Kretz, R., 1983. Symbols for rock-forming minerals. Am. Mineral., 68:277-279.

Kuniyoshi, S., and Liou, J. G., 1976. Contact metamorphism for the Karmutsen volcanics, Vancouver Island, British Columbia. J. Petrol., 17:73-99.

Leake, B. E., 1978. Nomenclature of amphiboles. Am. Mineral., 63:1023-1053.

Liou, J. G., Maruyama, S., and Cho, M., 1985. Phase equilibria and mineral parageneses of metabasites in low-grade metamorphism. Mineral. Mag., 49:321-333.

1987. Very low-grade metamorphism of volcanic and volcaniclastic rocks-mineral assemblages and mineral facies. In Frey, M., Very LowGrade Metamorphism: New York (Blackie and Son), 59-113.

Lockwood, J. P., 1971. Sedimentary and gravity-slide emplacement of serpentinite. Geol. Soc. Am. Bull., 82:919-936.

Maruyama, S., Cho, M., Liou, J. G., 1986. Experimental investigations of blueschist-greenschist transition equilibria: pressure dependence of $\mathrm{Al}_{2} \mathrm{O}_{3}$ contents in sodic amphiboles-a new geobarometer. In Evans, B. W., and Brown, E. H. (Eds.), Blueschists and Related Eclogues. Mem. Geol. Soc. Am., 164:1-16.

Maruyama, S., and Liou, J. G., 1987. Petrology of Franciscan metabasites along the jadeite-glaucophane type facies series, Cazadero, California. $J$. Petrol., 29:1-37.

Moore, D. E., and Liou, J. G., 1980. Detrital glaucophane schist pebbles from Franciscan metaconglomerates of the northeast Diablo Range, California. Am. J. Sci., 280:249-264.

Mottl, M. J., Haggerty, J. A., and Scientific Party of Ocean Drilling Program Leg 125, 1989. Upwelling of Cl-poor, S-, and C-rich waters through a serpentinite seamount, Mariana forearc: ODP Leg 125. Eos, 70:1382.

Nakajima, T., Banno, S., and Suzuki, T., 1977. Reactions leading to the disappearance of pumpellyite in low-grade metamorphic rocks of the Sanbagawa metamorphic belt in central Shikoku, Japan. J. Petrol., 18:263-284.

Newton, R. C., and Smith, J. V., 1967. Investigation concerning the breakdown of albite at depth in the earth. J. Geol., 75:268-286.
Nitsch, K. H., 1968. Die Stabilität von Lawsonit. Naturwissenschaften, $55: 388$.

Otsuki, M., and Banno, S., 1990. Prograde and retrograde metamorphism of hematite-bearing basic schists in the Sanbagawa belt in central Shikoku. J. Metamorph. Geol., 8:425-439.

Platt, J. B., Liou, J. G., and Page, B. M., 1976. Franciscan blueschist facies metaconglomerates, Diablo Range, California. Geol. Soc. Am. Bull., 87:581-591.

Sakakibara, M., 1986. A newly discovered high-pressure terrane in eastern Hokkaido, Japan. J. Metamorphic Geol., 4:401-408.

Seki, Y., Oki, Y., Matsuda, T., Mikami, K., and Okumura, K., 1969. Metamorphism in the Tanzawa Mountains, central Japan. J. Jpn. Assoc. Min. Petrol. Econ. Geol., 66:1-24, 49-75.

Shipboard Scientific Party, 1981. Site 453: west side of the Mariana Trough. In Uyeda, S., Ben-Avraham, Z., et al., Init. Repts. DSDP, 60: Washington (U.S. Govt. Printing Office), 101-123.

Suppe, J., 1972. Interrelationships of high-pressure metamorphism, deformation and sedimentation in Franciscan tectonics, U.S.A. 24th Int. Geol. Congr., Sect. 3, 552-559.

Takeuchi, H., and Uyeda, S., 1965. A possibility of present-day regional metamorphism. Tectonophysics, 2:59-68.

Uyeda, S., and Ben-Avraham, Z., 1972. Origin and development of the Philippine Sea. Nature, 240:176-178.

Watanabe, T., and Maekawa, H., 1985. Early Cretaceous dual subduction system in and around the Kamuikotan tectonic belt, Hokkaido, Japan. In Nasu, N., Kobayashi, K., Kushiro, I., and Kagami, H. (Eds.), Formation of Active Ocean Margins: Tokyo (Terra Sci. Publ.), 677-699.

Date of initial receipt: 17 September 1990

Date of acceptance: 7 May 1991

Ms 125B-131 